\title{
An Early Christian Arabic Account of the Creation of the World
}

\author{
Kirill Dmitriev
}

\section{Introduction}

More than most phenomena of Late Antique religious culture, the frequent reshapings of the myth of creation reveal how strongly this era was affected by interreligious relationships. As a result, its textual manifestations are extremely multifaceted, crossing the borders of different religious systems. Going back to ancient oriental patterns, the Biblical account of the creation of the world goes through a long history of its reception as a constituent of both Jewish and Christian traditions until it finally finds its way to Islamic culture. Formal similarities between the Qur'anic creation theology and certain Jewish or Christian sources respectively should not therefore be viewed as corruption of an 'original' motif, but rather as evidence of the common Late Antique cultural heritage that is adopted and modified in the Qur'an. This paper's focus of study, a poem of 'Adi b. Zayd al- ${ }^{\mathrm{C}}$ Ibādi (d. ca. 600) about the creation of the world and the fall of man, serves as an example of a text related to the literary milieu of the Qur'an and helps to place the latter in the context of the culture and era in which it emerged.

The main problem that besets the study of early Arabic culture, especially with concern to its religious aspects, is the problem of the authenticity of sources. This holds particularly true with respect to early Arabic poetry. The subject of this paper is a poetic work the written form of which can be traced back to a time no less than two hundred and fifty years after its supposed composition at the end of the fifth century CE. How justified can the usage of such a late document be for the study of the literary background of the Qur'an? This question has both a historical and a hermeneutical implication. Historically, one should proceed from the fact that the tradition of Arabic poetry has its roots in the pre-Islamic epoch and, despite a long process of transmission in mainly oral form, is more or less authentically preserved in the written sources currently available to us. ${ }^{1}$ In a recent study on Arabic tribal poetry as an ethnographic source that exhibits an uninterrupted continuity from pre-Islamic times through to the present day, Maxim Vasilenko stresses the multi-functionality and deep social integration of Arabic verse. ${ }^{2}$ This can still be observed and documented. ${ }^{3}$ Thus, research in contemporary Arabic tribal poetry shows that at all points in its history, this poetry

\footnotetext{
Wagner, Grundzüge, 12-29.

Vasilenko, Plemennaya poeziya, 9.

A recent publication on this subject is Suvorov, Al- ${ }^{c}$ Urr i Samar.
} 
has been inseparably linked with the social life and ceremonial practices of Arabic tribal society. As such, it has a clearly evident historical dimension.

The range of accuracy in the transmission of early works of Arabic poetry requires individual investigation of each particular case. Comparing existing studies on the poetry of Umayya b. abī aș-Ṣalt, Tilman Seidensticker came to the conclusion that it should be possible to arrive at objective criteria for determining the authenticity of early Arabic poems. ${ }^{4}$ As has been noted by Gustav von Grünebaum, ${ }^{5}$ along with the analysis of the vocabulary and content of texts, an investigation of the development of literary forms and schools of early Arabic poetry is also apt to provide essential criteria. Furthermore, much closer attention than has been customary should be paid to the history of the transmission of the texts and the evidence it provides with regard to their later reception. ${ }^{6}$ This can be achieved only through an extensive analysis of a wide range of textual materials. Unfortunately, publications offering reliable analytical material, like Marek Dziekan's book on the poetry of Quss b. Sāi ida al-Iyādīi, ${ }^{7}$ or Vladimir Polosin's vocabulary of ${ }^{\mathrm{c}} \mathrm{Absite}$ poets, ${ }^{8}$ remain relatively rare.

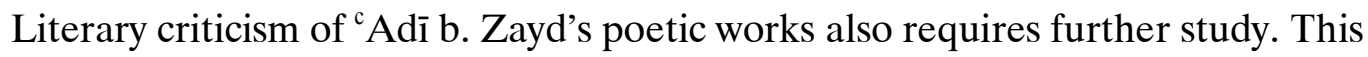
is however beyond the scope of the present paper, which will focus on one particular poem and the analysis of its lexical and thematic composition. Combined with the historical investigation of the poem's probable origin in the Nestorian milieu of al-Hiira provided by Isabel Toral-Niehoff, ${ }^{9}$ textual criticism can make a substantial contribution to the text's interpretation. Although these approaches bring to light important evidence for the poem's authenticity, they cannot yield an irrefutable solution of the question of authenticity. Yet the issue of where the text is to be historically located should not prevent a broader hermeneutical discourse. Thomas Bauer accurately points

\footnotetext{
Seidensticker, “Authenticity.”

Grünebaum, "Pre-Islamic Poetry," Grünebaum, "Zur Chronologie.”

6 The analysis of the textual evidences of the poem presented indicates a constant process of transmission of a common source. The character of several reading variants shows very clearly that these occurred as a result of the text's reinterpretation in the environment of its later transmission. These changes, however, only occur within the framework provided by the original text and can in no way be described as systematic forgery. For further details on the textual transmission of the poem, the reader is referred to the appendix.

7 Textual and literary analysis brought Dziekan to the conclusion that 36 out of the 66 works attributed to Quss b. Sāi ida can be regarded as pre-Islamic, see Dziekan, Quss Ibn Sācida, 229.

8 Polosin, Slovar.

9 Toral-Niehoff, "Gestaltung des Sündenfalls.”
} 
to the unjustified neglect of early Arabic literature as a source for the contextual study of the Qur'an, which he views as resulting mainly from an incorrect methodological approach towards pre-Islamic poetry. ${ }^{10}$ Following his argument that poetry is an indispensable source for any study of early Arabic culture, this current paper presents a poetic work, which is directly linked thematically to the issue of the Qur'an in context.

\section{The poet: ${ }^{\mathrm{c}}$ Adī Ibn Zayd al- ${ }^{\mathrm{C}} \mathrm{Ibādi}$}

The biographical information available on 'Adī b. Zayd has been recently summarized by Isabel Toral-Niehoff and Theresia Hainthaler. ${ }^{11}$ Here, it is sufficient to mention that 'Adī's life was intimately connected with the city of al-Hìra, where he was born in the Middle of the sixth century and was executed around the year 600. Al-Hiira was located in South Mesopotamia, in the area where later the town of Kufa was founded. Beginning in the mid-fifth century, al-Hīra became one of the largest and most important Arab cities. ${ }^{12}$ Its active relationships with Persia, Byzantium and Arabia played a significant role in both political and cultural development. Al-Hīra's significance within the cultural history of the Arabs derives not only from the fact that it cultivated an urban lifestyle that differed from the traditional Bedouin way of life, but more importantly from the fact that it served as a center of cross-cultural exchange where Arabs had direct access to the Late Antique heritage. ${ }^{13}$ Due to this symbiosis, Arabic culture received a significant impetus from al-Hīra. According to Islamic historians, even the Arabic script may have been invented in al-Hiira, a view that in Gerhard Endress' opinion reflects the position of al-Hïra as a central "connecting point of Aramaic-Hellenistic culture and the pre-Islamic Arabic world." ${ }^{14}$

The topic of the development of Arabic literacy also represents a remarkable aspect in the biography of ${ }^{c}$ Adī b. Zayd, who is perhaps the most prominent Christian Arabic poet of al-Hiira. ${ }^{15}$ After all, he is credited with the official introduction of Arabic

10 See Bauer's contribution to this volume.

11 Toral-Niehoff, "Gestaltung des Sündenfalls," 239-240; Hainthaler, "Adīi ibn Zayd,” 158-163.

12 Shahid, "Al-Hīra." According to Ugo Monneret de Villard, al-Hīra "had to be a great city, with intense commercial traffic, so much that arrival was from the Euphrates and the Canals, as well as vessels from India and China,"-see Monneret de Villard, Le chiese, 32; quoted upon: Comneno, "Nestorianism," 44.

13 Shahid, "Al-Hīra," 462.

14 Endress, “Arabische Schrift," 170.

15 For bibliographical references on the history of Christianity in al-Hīra refer to Hainthaler, "Adì ibn Zayd," 164-165; see also Toral-Niehoff, "Gestaltung des Sündenfalls,” 252. 
script to the Persian court at Ctesiphon. ${ }^{16}$ c Adī b. Zayd must have known and used the Arabic script in his work as a royal secretary, and he might therefore have applied his linguistic skills to his poetical work as well. This assumption appears particularly plausible if one takes into consideration that his poems were composed primarily in a solitary cell ${ }^{17}$ from which ${ }^{c}$ Adi $\mathrm{b}$. Zayd is reported to have continued writing until the tragic end of his life. ${ }^{18}$ Even if manifestations of literacy in pre-Islamic Arabia are limited to "documents of an 'archival' character," as Alfred Beeston claims ${ }^{19}$ in the case of ${ }^{\mathrm{c}}$ Adī b. Zayd, who was both a poet and an official, the possibility that he documented his verses in writing is quite high. The question of transmission, however, remains open, and is only hypothetically illuminated by this assumption.

Further details can be provided by the later history of transmission. The collection of ${ }^{c}$ Adī b. Zayd's poetic works was carried out by Hishām b. al-Kalbī (d. ca. 206/821), and his Kitāb 'cAdī b. Zayd was used by both al-Iṣfahānī (285/897-356/967) and at-Tabarī (615/1218-694/1295). Tradition portrays Ibn al-Kalbī as an expert of Arabic genealogy and pre-Islamic Arabic history. Ibn al-Kalbī's lost work on the churches and monasteries of al-Hīra was most likely based on his studies of the archives of al-Hīra's Christian communities. ${ }^{20}$ In view of the fact that Ibn al-Kalbī even consulted Palmyrenic texts and was informed of findings from Yemen, ${ }^{21}$ it stands to reason that he would certainly have made use of the material available to him at al-Hira, as it bordered directly on his hometown of Kufa. ${ }^{22}$ It thus appears probable that the later transmission of the works of ${ }^{\mathrm{c}} \mathrm{Ad} \overline{\mathrm{i}} \mathrm{b}$. Zayd may go back to a reliable source. Even though the origins of this transmission process remain undocumented, its later manifestations deserve close attention, since the history of any text is always a history of its reception as well.

Among the preserved works of ${ }^{c} \mathrm{Ad} \overline{\mathrm{l}} \mathrm{b}$. Zayd is a poem concerning the creation of the world, the creation of man, and the latter's fall. This poem has already been the

16 Aghāni, vol. 2, 102; see also Horovitz, “c Adī ibn Zeyd,” 38.

17 Aghāni, vol. 2, 110.

18 Aṭ-Ṭabarī, Tārīkh, 1020-1021, 1023, Aghāni, vol. 2, 110-115.

19 Beeston, “Antecedents," 235.

20 Attalah, "Al-Kalbī," 494.

21 Attalah, "Al-Kalbī," 494.

22 The urban landscape of al-Hīra shifted already in pre-Islamic time "northwards, till it reached the area occupied by present-day Kufa," (see Talbot Rice, "Hira," 261); and in the ninth century al-Hīra and Kufa were considered to be two names of one and the same city, see Hainthaler, "Adì ibn Zayd," 165. 
subject of critical analysis. ${ }^{23}$ However, this work cannot be viewed as complete. The text of the poem has not yet been published as a single, complete entity, but rather in several fragments. ${ }^{24}$ For this reason, a new attempt to compile the text of the poem ${ }^{25}$ and to analyze it in relation to its literary context is necessary.

Introduction (vv. 1-2)
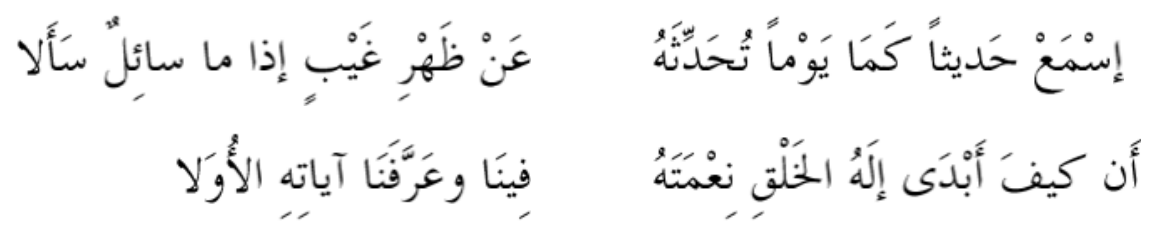

Listen to a story, so that one day you may retell it

from memory, if a questioner asks (you)!

How the God of creation let appear his grace

to us and taught us his first signs.

The words isma ${ }^{c}$ hadithan, "listen to a story," set the mood of the poem right from its beginning. The introductory phrase echoes Jewish and Christian liturgy and their typical requests for the community to listen, especially before the recitation of scripture. The call "listen!" is also distinctive of Syrian homiletic literature. ${ }^{26}$ An echo of this Jewish and Christian liturgical practice of announcing the recitation of scripture can also be found in the Qur'an. The word hadith often precedes the Qur'anic narrations of Biblical

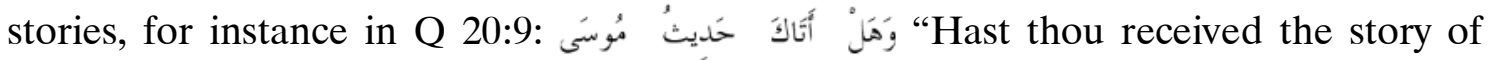
Moses?"27

23 Hirschberg, Lehren, 82-84, 105-108; Gabrieli, “Adī b. Zaid,” 85-86; Wagner, Grundzüge, 167; Rezvan, Koran, 64, 84-85; Toral-Niehoff, "Gestaltung des Sündenfalls."

24 The edition of al-Mu aybid ( $D^{\circ} \bar{I}$ ān ${ }^{c} A d \bar{i} b$. Zayd, 158-160) also does not include all textual material.

25 See the appendix.

26 See The Homilies of Aphraates, 239, as an example.

27 Translations of the Qur'an follow Arberry, The Koran. As remarked in the introduction, general lowercasing and other minor modifications have been adopted. 
The introductory lines also imply a dialogical setting, serving the purposes of both preaching and instruction-a motif to be found in both Jewish and Christian tradition that ultimately goes back to Biblical precedents (Exod. 12:26-27, Deut. 6:2021, 1 Pet. 3:15). The use of dialogue is a characteristic feature of Late Antique poetry and homiletic prose in both Greek and Syriac. ${ }^{28}$ Dialogical and homiletic characters are crucial attributes of the most important forms of early Syriac poetry-madrāshā, sogittā and $m \bar{e} m r a{ }^{29}$ as well as the kontakion, a form of Byzantine liturgical poetry found in the sixth century that was significantly influenced by Syriac hymnography ${ }^{30}$ The Qur'an also

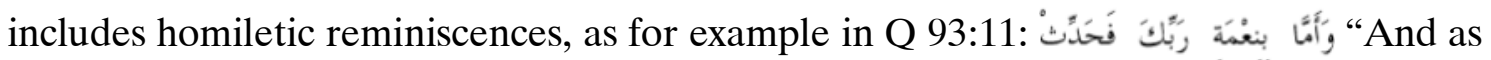
for thy Lord's blessing, declare it."

Close attention ought to be paid to the expression, abdā nic matahū, "He let his grace appear," in the second line of this poem. The word, nicmatun, "grace," is used several times in the Qur'an, as in Q 35:3: "O men, remember God's blessing upon you." ${ }^{31}$ The concept can also be found frequently in the Bible, ${ }^{32}$

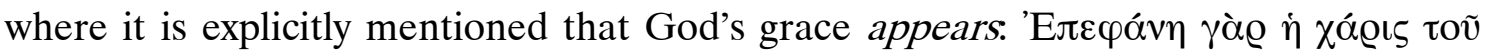

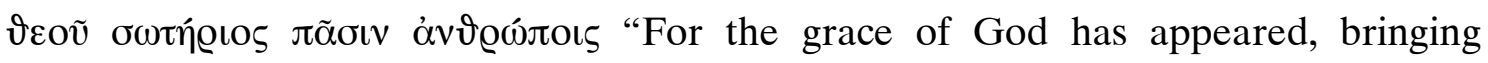
salvation to all." ${ }^{33}$ The verb abdā, "to let appear," together with the following verb, carrafa, "to let someone know" or "to teach," emphasize the hermeneutical aspect of the poem. This is evident from the text's first lines, which define the perspective from which the creation story will be viewed throughout the poem. The quasi-historical report of Genesis is placed in a hermeneutical light where the recognition of God's signs forms the basis for proclaiming his glory. As in later Biblical accounts, especially those of the Psalms and the story of Job, the hermeneutical perspective is central to Qur'anic creation theology. It seems, therefore, that it is not due to coincidence that on the lexical level the verb 'arrafa also parallels the Qur'an. No other evidence for ${ }^{c}$ arrafa in the second stem or, according to two recensions of the poem, ${ }^{c}$ allama, ${ }^{34}$ can be found in pre-Islamic poetry.

28 Brock, "From Ephrem to Romanos," 141.

29 See Brock, "From Ephrem to Romanos," Brock, "Syriac Dispute Poems."

30 Asmus, "Tworchestwo," 192.

31 Further references Q 2:211.231, 3:103, 5:11.7.20, 8:53, 14:16.28.34, 16:18.53.83.114, 26:22, 33:9, 37:57, 39:8.49, 43:13, 68:49, 92:19.

32 At least 348 references.

33 Translations of the Bible, if not indicated otherwise, are given according to the New Revised Standard Version.

34 See appendix. 
In the Qur'an, 'carrafa is used twice, in Q 47:5-6 and in 66:3. 'Allama appears

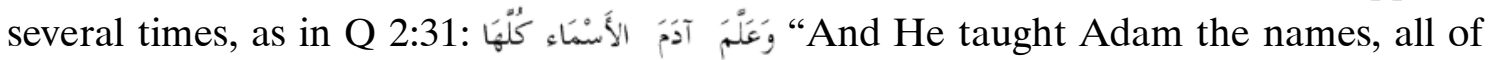
them." However, what matters is not this formal lexical correspondence but rather the semantics of the word āya (pl. āyāt) meaning "sign," which has evident hermeneutical implications in the poem as well as in the Qur'an. The usage of ${ }^{c}$ arrafa/ ${ }^{c}$ allama in connection with āyāt has clear parallels in the Qur'an, where signs are portrayed as a crucial means of communication between God and man. The Qur'an describes this process with the verbs "to bring" (atâ, $j \bar{a}^{\circ} a$, Q 2:106, 211, 43:47), "to bring down," "to reveal" (nazzala, anzala, Q 6:37, 10:20), "to send" (ba catha, Q 10:75), but also "to explain," "to make clear" (Q 5:75, 6:46, 7:174, 9:11), "to tell," and "to recite" (dhakkara, qașsa, Q 6:130, 8:31, 10:71). ${ }^{35}$ The Arabic āya is related to the Hebrew ôth, meaning in biblical and rabbinical usage "sign" or "miracle." However, in contrast to the latter, āya in the Qur'an refers to both non-linguistic as well as linguistic communication. ${ }^{36}$ As such, it refers to God's revelation in general. A similar tendency towards the extension of the semantic field of the concept of "sign" is found in Syriac literature prior to the Qur'an. Here, the word $\bar{a} t h \bar{a}$, "while being used precisely as the

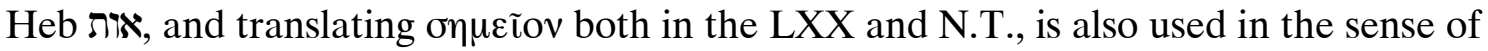
argumentum, documentum (PSm, 413) ${ }^{37}$ and thus approaches even more closely than אית the Qur ānic use of the word." ${ }^{38}$ In the Syriac translation of the Gospel according to John, āthā refers to signs by which Jesus manifested himself as the Lord. ${ }^{39}$

The expression, fa- ${ }^{c}$ arrafanā àyātihì l-uwalā, in the second line of the poem represents early evidence for the hermeneutic meaning of the word āya in Arabic, which probably developed in correspondence with the Syriac āthā and is significant for the Qur'anic concept of signs. Against the background of the Christian idea of the logos creator" $^{40}$ (John 1:1.14), the description of the creation of the world as "first signs" does not appear surprising. Creation is the manifestation of the divine Word $\left(\lambda \circ \gamma^{\prime} \circ\right)^{41}$ and as

\footnotetext{
35 Abrahamov, "Signs," 8.

36 Abrahamov, "Signs," 6-7.

37 Jeffery here refers to Payne Smith, Thesaurus, vol. 1, 413 (K. D.).

38 Jeffery, The Foreign Vocabulary, 73.

39 Payne Smith, Syriac Dictionary, 31. See John 2:11 as an example. For the New Testament is a disassociation from the legitimization of the religious authority through signs as means of nonlinguistic communication characteristic (Mat 16:4, 24:3ff, 24:24, Mar 8:11-12, Luk 11:16 etc.).

40 Compare Ps. 33:6, 9, and also Q 2:117, 3:47, 3:59, 6:73, 16:40, 19:35, 36:82, 40:68, 50:38.

41 In Greek $\lambda$ ó $0 \varsigma$ means not just "word," but also "language," "speech," "proof," "doctrine," and "reason."
} 
such has to be understood as the first act of revelation. Even if āya in pre-Islamic poetry indicates only "signs," "road-signs," 42 it is likely that the Arabic word's semantic field was extended and interpreted hermeneutically among Arabic Christians who were familiar with Syriac tradition. The poem's use of the word ayya thus ought to be explained in terms of a shared linguistic and theological context rather then in terms of the poem's textual dependence on the Qur'an.

The creation of the world (vv. 3-7)
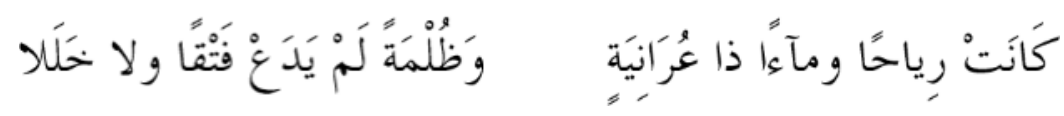

They were winds, raging water and darkness. He left neither rent nor gap.

No parallel for the mention of winds can be found in either the Qur'an or the Bible. In several Late Antique works, wind or air are often mentioned among the original elements such as water, fire and earth. ${ }^{43}$ However, it is unlikely that verse $3 a$ does in fact allude to classical cosmology. It is much more probable that the terms "winds and ranging water" are meant to describe original chaos, as known from Gen. 1:2 as toh $\bar{u}$

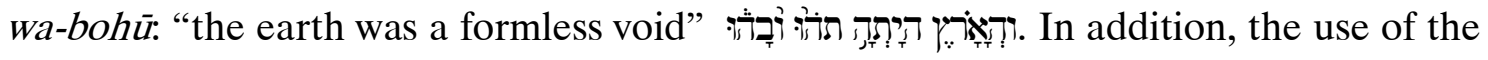
word "wind" in its plural form stresses the descriptive meaning of the passage. This discourages allegorical interpretation of the kind found in the Babylonian Talmud and other writings, where the wind is identified as one of the cosmogonic elements. ${ }^{44}$

The reference to darkness and a primordial unity of the whole of creation are

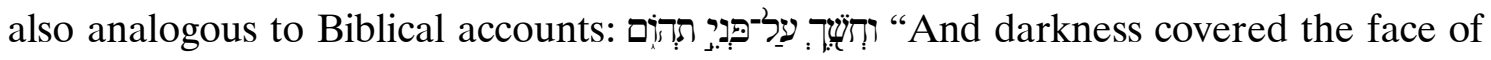
the deep" (Gen. 1:2). By contrast, the Qur'an employs the word zulmatun only in its plural form, zulumāt, which only once appears in the context of the creation of the

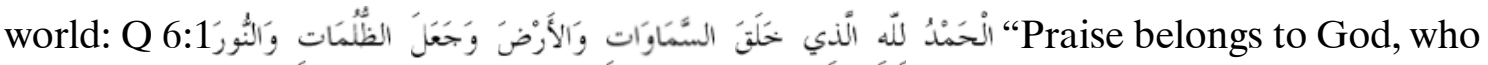
created the heavens and the earth and appointed the shadows and light." This verse, however, should not be read as referring to original darkness, but rather to night and day and the succession of one following the other (cf. Q 3:190). Water, too, is

\footnotetext{
42 Imrū ${ }^{\circ}$ al-Qays, LXV:1, see Ahlwardt, The Divans, 160; compare also Q 26:128.

43 Speyer, Die biblischen Erzählungen, 15; see also Toepel, Legenden, 25-36.

44 Toepel, Legenden, 35-36.
} 
mentioned only once in the Qur'an in the context of creation, namely, in Q 11:7. There its connotation differs significantly from the way in which water appears in the poem:

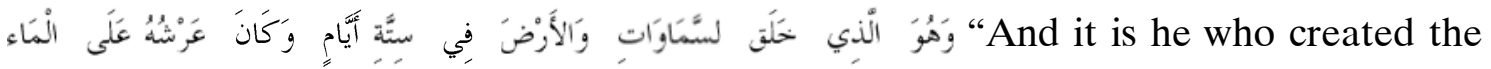
heavens and the earth in six days, and his throne was upon the waters." 45 According to the Qur'an, then, water existed prior to the creation of the world. The Qur'an, therefore, does not appear to subscribe to the idea of a creatio ex nihilo. ${ }^{46}$ Although this concept is of course not explicitly mentioned in the Bible either, it is generally assumed in later Christian theology. The wording of line 3 also does not explicitly exclude the possibility that matter might have been preexistent. However, one should not overlook the fact that the linguistic construction of kāna + accusative syntactically subordinates the words "winds" and "water" as compound predicates to the word "signs" in the preceding line as its subject. Thus, these elements are seen as part of the divine work of creation.
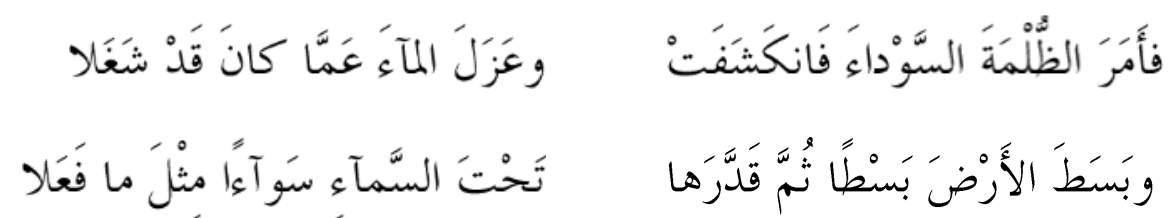

Then he commanded the black darkness and it became disclosed, and he separated the water from what was occupying him (before).

And he spread the earth out, then he determined it under the sky, adjusted (to it) as he made (it).

Lines 4-5 recall in a shorter form the events of the second and third days of the creation of Genesis. Biblical images are evoked such as the partition between light and darkness (Gen. 1:4), the separation between the water under and above the firmament (Gen. 1:6-7) and the formation of dry land (Gen. 1:9-10). The poem essentially follows the chronology of the Biblical account of creation. The wording of the lines, however, exhibits no clear similarities to the text of Genesis.

Basața l-arda bastan is a figura etymologica, meaning literally "he spread the earth out by spreading." One version replaces bastan with bisătan (TA, LA). The

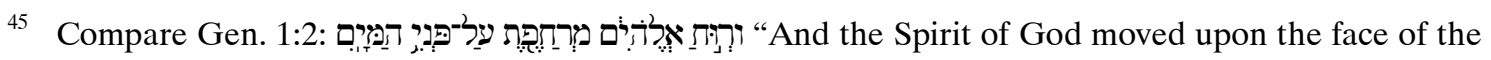
waters." (King James).

${ }^{46}$ O'Saughnessy, "Creation from Nothing." 
translation would then be "he spread out the earth like a carpet." This seems, however, to be a later reading. The primary meaning of the root $b-s-t$ is "to spread out," "to stretch out." The idea that God spread out the earth is reflected in the Bible, cf. Isa. 42:5: "Thus says God, the Lord, who created the heavens and stretched them out, who spread out the earth and what comes from it." ${ }^{\prime 7}$

The Qur'an also discusses the spreading of earth in Q 2:22: الَذي جَعَلَ لَكُمُ الأَرْضَ فرَاشَا

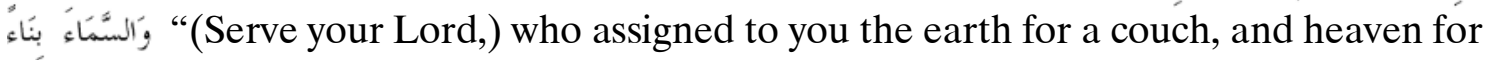
an edifice." The word firāshun, which Arberry translates here as "couch," has as its primary meaning "plain," "plain land." The verb farasha means "to level," "to make plain," as well as "to make something a bed." This meaning is clearly attested in

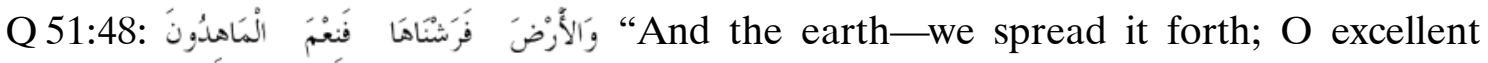
smoothers!" Along with farasha, the spreading of earth is described in the Qur'an with the verbs madda (13:3, 15:19, 50:7, 84:3), sataha (88:20) and taḥā (91:6). Basața is not used in the Qur'an in this context. ${ }^{48}$
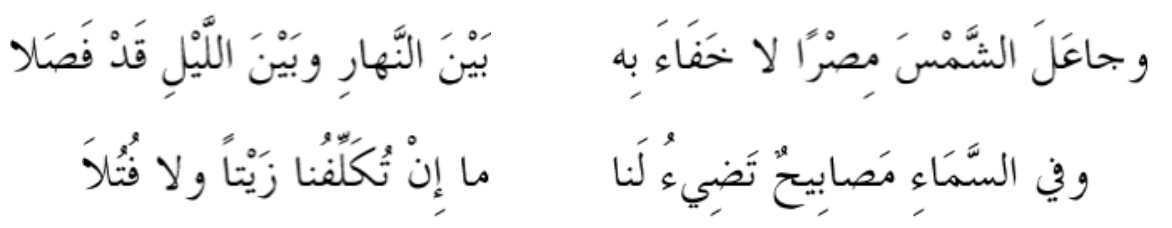

And he made the sun a limit that has no veil, it separates the day from the night.

And lights shine for us in the sky, without burdening us with oil or wick.

In pre-Islamic poetry, the word mișrun has the primary meaning of "limit," "age-limit." Therefore, the fist words of line 6 express the notion that the sun serves to mark the passage of time. The same function of the sun is depicted in Gen. 1:14. A parallel can

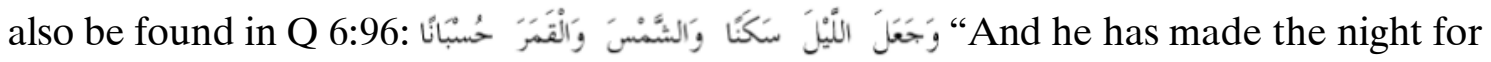
a repose, and the sun and moon for a reckoning." This similarity, however, is only one of content. There is nothing in lines 6 and 7 of the poem that is immediately recognizable as having been borrowed from either the Bible or the Qur'an. The

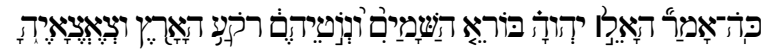

48 Basata is used in the Qur'an with the meaning "to spread out the hand" (Q 13:26, 17:30, 28:82, 29:62, 30:37, 34:36, 34:39, 39:52, 42:12). 
statement concerning the absence of a veil remains unclear. One possible interpretation is that this may refer to the notion that the transition from day to night and the course of time occur smoothly, without a noticeable separation.

The idea that the sun is put into service for man is resumed in line 7. This seems to be an independent poetic idea without direct sources in canonical religious texts. ${ }^{49}$ It does, however, possess a rhetorical function. The reference to the listeners ("lights shine for us") recalls the dialogical framework and the didactic character of the poem.

Creation of man, paradise, and woman (vv. 8-11)
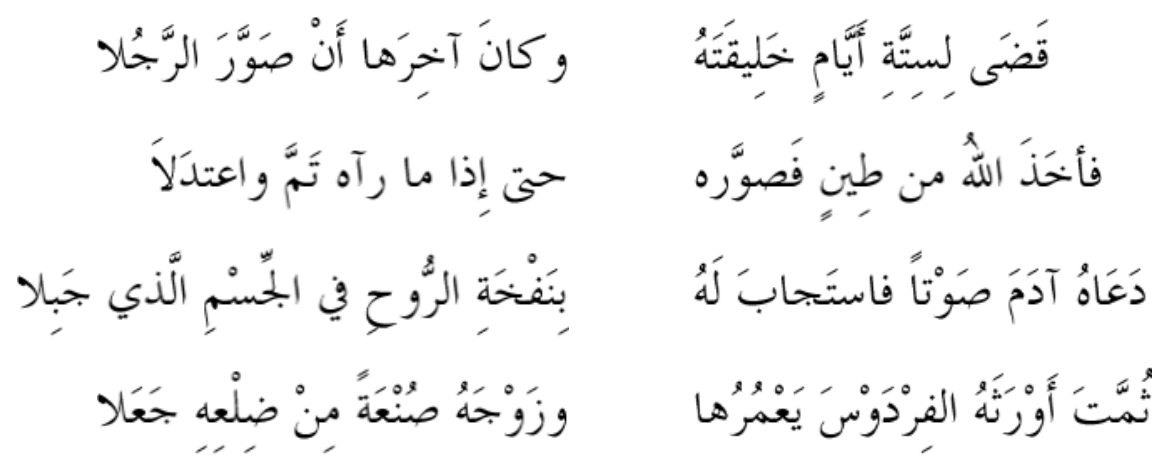

He fulfilled his creation in six days and it was its last part, that he shaped man.

God took clay and shaped him until he saw him to be perfect and standing upright.

He called him with a (raised) voice "Adam!," and the latter answered him thanks to the blowing of the spirit into the body that he formed.

After that he bequeathed to him paradise, so that he might inhabit it, and he made his wife, built out of his rib.

The number of days of creation is defined as six in the Bible (Gen. 2:2, Exod. 20:11, 31:17). This number is also frequently reported in the Qur'an $(7: 54,10: 3,11: 7) .{ }^{50}$ Both sources also imply that the creation of man was the final act of creation. Its depiction in the lines 8 through 11 is close to the so-called "second creation story" of Genesis (2:4-

\footnotetext{
49 A remote parallel can be found in the parable on the carelessness of the birds in Matt. 6:26.

50 Further references Q 25:59, 32:4, 50:38, 57:4.
} 
25). The Biblical origin of lines 8 and 9 can be seen by the use of the verb șawwara. The root $s-w-r$ contains the meaning "image," "form"; sawwara thus means "to shape," "to form." In the present context, it indicates that the poet was aware of the Biblical concept of man's creation in the image of God. Gen. 1:26 reads: "Then God said, Let us make humankind in our image, according to our likeness." ${ }^{51}$ Here the Hebrew text uses the verb āśa to mean "make." In the Syriac version, the term used is " bad. Parallel to this, Gen. 2:7 uses Hebr. yāṣar, Gr. $\pi \lambda \alpha \dot{\alpha} \sigma \omega$, "to shape," "to form"” and Syr. $g^{e}$ bal, "to

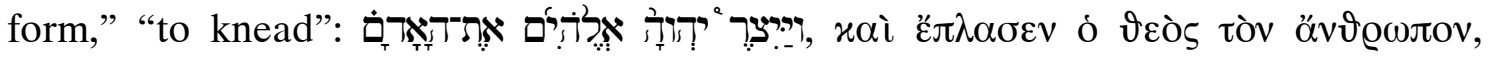
" "Then the Lord God formed man."

The creation of humans in the image of God has an essential Christological dimension that is related to the ideas of incarnation and Christ as the second Adam. ${ }^{52}$ Ephrem the Syrian (ca. 306-373), an outstanding representative of early Syriac Christianity, understands the creation of Adam as a revelation of Christ:

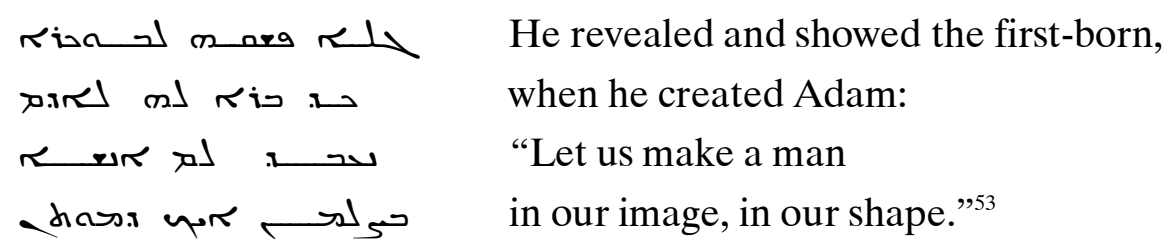

This parallel of Jesus and Adam also makes its appearance in the Qur'an. However, in this case, it is used in an inverse fashion to disprove man's likeness with God and, as

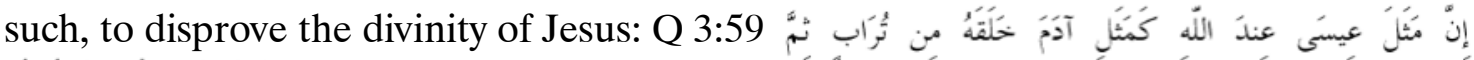
قَالَ لَهُ كُن فَكَكُونُ 'Truly, the likeness of Jesus, in God's sight, is as Adam's likeness; hé created him of dust, then said he unto him, 'Be,' and he was." The Qur'an very firmly contradicts the concept that humanity was created in God's image. This is also exhibited through various linguistic means. The Qur'an consistently describes the creation of the first human being by employing the verb khalaqa. Sawwara, on the other hand, is only used in the Qur'an to refer to subsequent work of God on humans. According to the

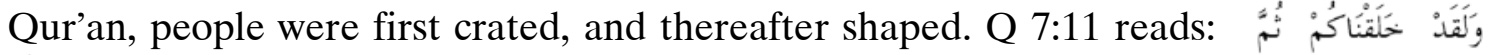
"We created you, then we shaped you."

51

The Septuagint renders Hebrew șelem, "image," with cixóva, and the Peshitta with $\sim_{5}$ (salmo).

52 Rom. 15:14f., 1 Cor. 15:21-22, 45-47.

53 De Fide VI:7, see Beck, Hymnen, 26-27.

${ }^{54}$ Compare Q 38:71-72. 


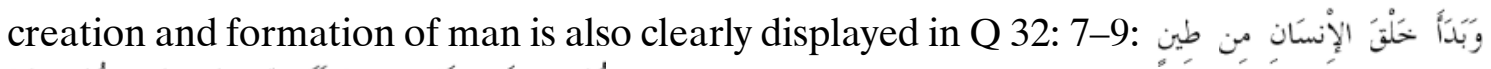
“'And he originated the creation of man out of clay, then he fashioned his progeny of an extraction of mean water, then he shaped him," and

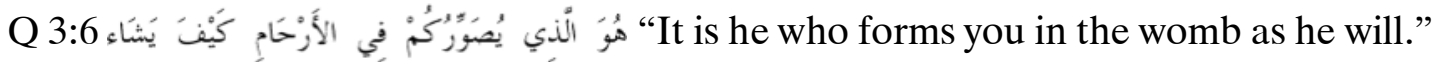

There is an important semantic difference in the usage of the verb sawwara in the Qur'an and its equivalents in Biblical account of creation. The Qur'anic sawwara is limited exclusively to the physiological shaping of the human (Q 40:64 and 64:3: صَوَزَكُمْ

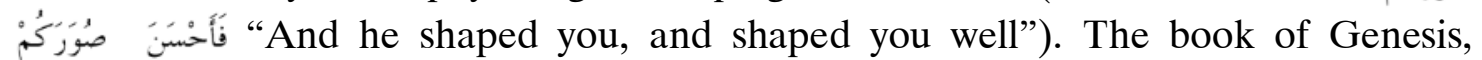
however, implies a shaping in the image of God. The context of the poem makes it obvious that the verb sawwara in line 8 conveys the Biblical concept.

What is also remarkable is the statement that the first human was shaped from tīn, "clay." The notion of the usage of clay in the creation of man can be found in early Semitic literature, both from Mesopotamia and Ugarit. ${ }^{55}$ The idea of man as clay and the creator as a kind of potter is also a Biblical motif ${ }^{56}$ (Isa. 64:7, Job 10:9). Job 33:6 reads:

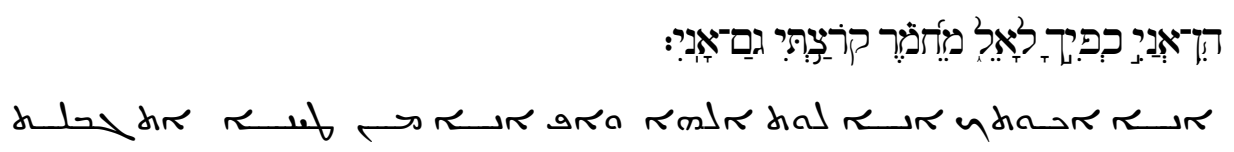

See, before God I am as you are; I too was formed from a piece of clay.

In the Qur'an the description of man as created from tīn occurs eight times. An example can be found in Q 6:2: هُو الْذي خَحَفَكُم مِّن طِين "It is he who created you of clay." T7 This is in fact a distinctive feature of Qur'anic language, since in early Arabic texts the word tinn is used quite seldomly. Only one reference to this can be found in pre-Islamic poetry, in the dīwān of the Jewish poet as-Samaw ${ }^{\circ}$ al b. ${ }^{~}{ }^{A}$ diyā (born ca. 560), VI:6:

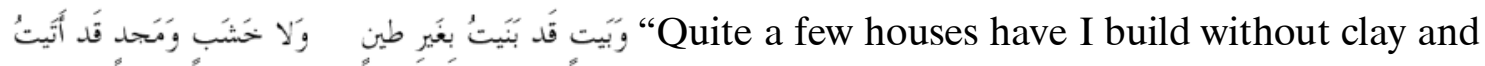
without wood, and I have won fame." ${ }^{58}$

55 Greenstein, “God's Golem,” 222.

56 The creation story of Genesis, however, does not speak of "clay" (Hebr. khomer, Syr. tīnā), but of "afar, "earth," "dust." The Septuagint has $\gamma \tilde{\eta}$, the Peshitta ri aح.

57 Further references Q 7:12; 17:61; 23:12; 32:7; 37:11; 38:71, 76.

58 Hirschberg, Der Dīwān des as-Samau ål, 27.

Some few references from the early Islamic time can be found in the mukhadramūn poets. In the following two examples the word tinn is used in the same anthropological context:

Umayya b. abī as-Ṣalt (d. ca. 631) (cf. as-Saṭī', 'Cmayya, 394): 
The infrequency with which the word tīn can be found in pre-Islamic Arabic poetry must be viewed in relation to its non-Arabic origin. Tin most likely came into Arabic as a loan-word from a North-Semitic language. Arthur Jeffery comments on the word tīnā, "clay," in Judaic-Aramaic and Syriac: "From the some source in the Mesopotamian area the word passed into Iranian, [...] and it was probably from the same source that it came as an early borrowing into Arabic." 59 One can thus assume with a high degree of certainty that an author like ${ }^{c}$ Adī b. Zayd, living in Mesopotamia, educated in Arabic and Persian, and exposed to the Syriac Christian tradition, would most likely have known the word tinn. Again, the poem's similarity with the Qur'anic wording is evidence of the poem's milieu of origin rather than of textual dependency on the Qur'an.

Also meaningful is the context in which the word tîn is used in line 9a. The following expression "perfect and standing upright" (9b) evokes the uniqueness of man among other creatures, the exceptional features that bear witness to his likeness to God. This is most probably also the content of the preceding passage, which utilizes the verb sawwara. Jewish tradition interprets the straightening of Adam as a consequence of the inspiration of his earlier body, ${ }^{60}$ and explicitly considers his ability to stand upright as evidence of his likeness to God: עמר על רגליו והיה מתואר בדמות אלהים "he stand on his feet and was adorned with the shape of God." ${ }^{61}$ The Qur'an does not talk about Adam's standing upright, and in only two places does the Qur'anic description of man's creation from clay (tīn) continue with God blowing his spirit into him (Q 32:7-9, 38:71-72), and

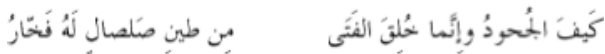

"How could someone deny? Verily man was created of clay (like) clay, of which baked pottery (is made)."

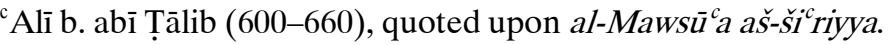

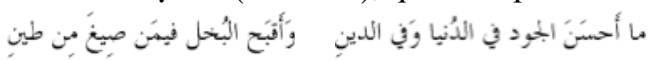

"Nothing is better than generosity in this world and in faith, and nothing is more abominable than stinginess in someone who is made out of clay."

59 Jeffery, The Foreign Vocabulary, 208.

60 Toepel, Legenden, 76.

61 Text see Sefer Priqe d Rabbi Eliezer, פרק אחד עשר, section line 2 from below; quoted upon Toepel, Legenden, 63. The later Christian tradition refers to the rising up of Adam in a soteriological context. See for example the account of The Cave of Treasures (2:15-16): "When he rose in full length and stood upright in the center of the earth, he planted his two feet on that spot whereon was set up the Cross of out Redeemer," see The Book of the Cave of Treasures, 53. 
here, too, the motif is not elaborated any further. Even Iblis' argument that man was created of as lowly a substance as clay is not refuted by appeal to God's creative breath (Q 38:76). The blowing of God's spirit into the first human is of course an echo of the Biblical tradition (Gen. 2:7, Job 33:4, cf. Rev. 11:11, John 20:22). In the framework of Islamic anthropology, however, it has significantly less ontological weight than it carries

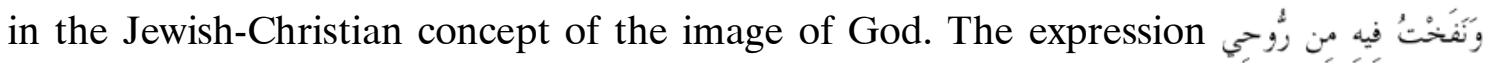
"And I breathed my spirit in him" in Q 15:29 and 38:72 is paralleled by the Syriac theologian Aphraat (290-370) "et insufflavit ei de spiritu suo." Hence, the corresponding nominal construction nafkhatu r-rūh in line $10 \mathrm{~b}$ of the poem must not necessarily be attributed to an Islamic source.

The fact that the poem is to be traced back, not to the Qur'an, but to a shared cultural milieu, is also indicated by the last word of the line 10, jabila, which does not appear in the Qur'an. Only in two Qur'anic passages can derivations from the root $j-b-I$ be found (jubillatun and jibillun). These terms, however, do not seem to be used in preIslamic or in early Islamic poetry. ${ }^{63}$ At the same time, their meaning in the Qur'an is not

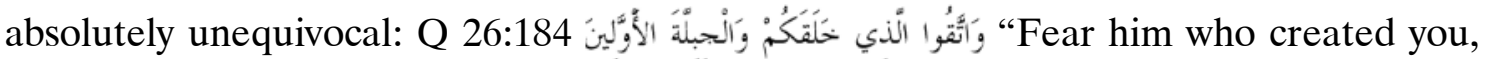

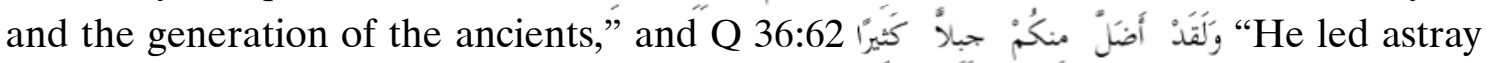
many a throng of you." Both passages, as Efim Rezvan points out based on their contexts ${ }^{64}$ deal with legendary ancient nations, and both must be viewed in relation to the fact that the term $j b l$ is found in inscriptions from Palmyra ${ }^{65}$ and Lihyan, ${ }^{66}$ where it signifies a "public meeting." The term $j b /$ hence belongs to the linguistic field of NorthArabic nations. Its North-Semitic origin is also evident in Syriac, where words with this root are common: the verb $g^{e} b a l$, for example, is used in the Syriac version of the previously quoted verse, Gen. 2:7: Syriac literature, too, the creation of man is generally described by $g^{e} b a l .{ }^{67}$ The use of the verb jabila in the text of the poem reveals the familiarity of its author with the

\footnotetext{
A2 Aphraatis sapientis, 800:4.

63 See also Rezvan, Koran, 64.

64 Rezvan, Koran, 65.

65 Starcky, Palmyre, 36.

66 Caskel, Lihyan, no. 71:5, 77:6-7, 87:3, 91:8, compare also no. 52.

67 References are numerous, compare for example the Syriac version of Clement of Rome's Epistle to Vergins: " sistan whom he had formed," see Clementis Romani Epistolae, 71:20, and also the sixth hymn of Ephrem the Syrian: sermed him at the beginning" (see Beck, Hymnen, 27).
} 
North-Arabic, especially the Syriac, linguistic milieu. This is also reflected in the Qur'anic terms jibillatun and jibillun.

A similar point applies to the description of paradise as al-firdaus in line 11. This is of course analogous to the Syriac fardayso. The Syriac version of the Bible uses fardayso quite often, whereas in the Qur'an, the word used to refer to paradise as it was inhabited by Adam is always al-janna. The word al-firdaus is used in the Qur'an only twice. In both cases, it refers to the paradise to be inherited by the believers, e. g. in Q

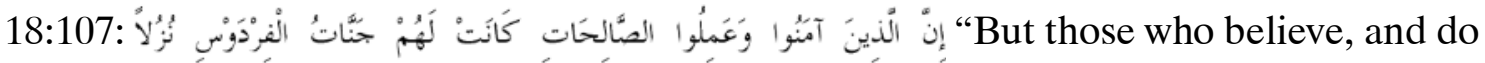
deeds of righteousness - the gardens of paradise shall be their hospitality." Al-firdaus occurs in the same context in Q 23:11, a verse that, like the text of the poem, also

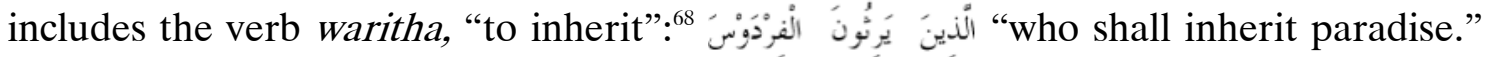
Despite this similarity, one can also observe differences between the two texts. The verb waritha is used in Q 23:11 in the first and not in fourth stem. Also, the Qur'anic passage discusses eschatology and not the creation of the world. The same notion that the believers will inherit eternal life in heaven is also an essential feature of the theology of the New Testament. In the Sermon on the Mount, which is not only a theological, but also a central liturgical text, it is written: "Blessed are the meek, for they will inherit the earth" (Mt 5:5). Its Syriac version employs the verb ireth, which corresponds to the Arabic waritha,- - rin adire.

The second half of line 11 displays further similarities with the Biblical account of creation. Firstly, there is a similar succession of events: first man is created (Gen. 2:7), then he is brought to paradise (Gen. 2:8.15), and finally his wife is created (Gen. 2:22). Secondly, the creation of woman from Adam's rib (Gen. 2:22) takes place. The Qur'an does not specify when the fist woman was created, and it merely reports

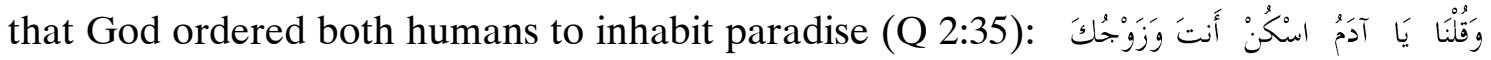

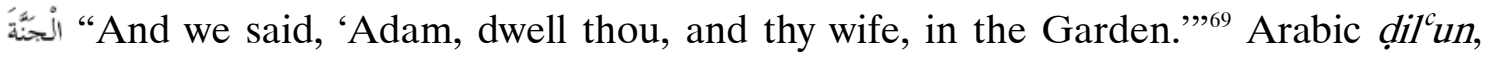
"rib," is exhibited in pre-Islamic poetry, but not in the Qur'an. The Qur'an can be read as implying that the first women was created from Adam; however, it does not mention

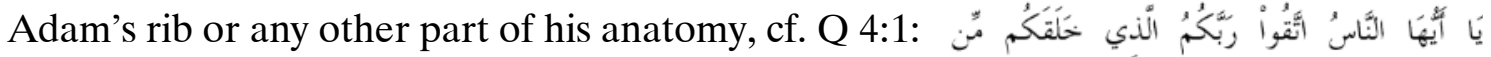
"Mankind, fear your Lord, who created you of a single soul, and from it created its mate." In contrast to this, Gen. 2:22 clearly states that Adam's wife

68 Cf. Q 21:105, and see Baumstark, “Arabische Übersetzung,” 184.

69 See also Q 7:19. 
was created of his rib: "And the rib that the Lord God had taken from the man he made into a woman and brought her to the man."

One should also notice that the creation of women is described in the poem with the word sun ${ }^{c} a t u n$ rather than with the Qur'anic khalaqa. The root $s-n^{-{ }^{c}}$ means "to make" in Arabic. This corresponds to Hebr. bāna and Syr. taqen of the Biblical text. Both verbs mean "to construct," "to form."

The first commandment (v. 12)

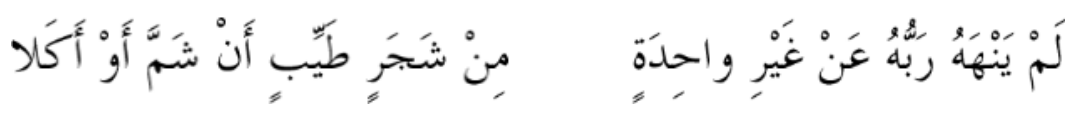

His Lord did not forbade him—with a single exceptionto smell or to eat from good trees.

The prohibition to eat from the tree of knowledge is mentioned both in Genesis (2:1617) and in the Qur'an (2:35, 7:19). According to both accounts, the receiver of the commandment is Adam. The essential difference, however, lies in the fact that in the Qur'an the prohibition refers explicitly to Adam and his wife, whereas in the Bible the commandment is given to Adam alone before the creation of Eve. In the verse 12 of the poem, Adam is the only human addressed. Despite the fact that the creation of women has been mentioned in the previous line, one cannot be sure whether it preceded the commandment, as lines 11 and 12 are syntactically not connected to one another.

The serpent and the fall of man (vv. 1318)

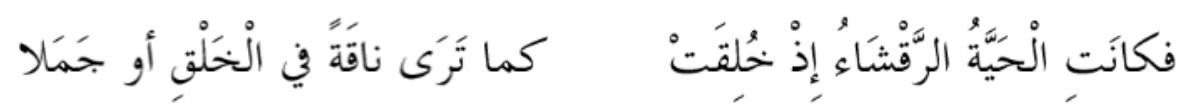

The serpent with black and white spots was, when it was created, as you see a she-camel in the shape or a he-camel.

The motif of the serpent displays another correspondence to the book of Genesis. The Qur'an attributes the seduction of the first human couple exclusively to the devil. ${ }^{71}$

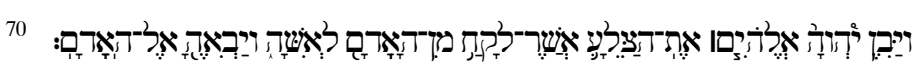


Absence of an explicit relation between the serpent and the devil in the poem is for Isabel Toral-Niehoff an important indicator that it is independent from the Qur'an. ${ }^{72}$

The development of the motif of the fall of humanity in Jewish and Christian transmission exhibits a gradual replacement of the serpent's figure by that of the devil. This transformation is completed in the Qur'an. ${ }^{73}$ It is interesting to note that in three Qur'anic stories of paradise, preceded by an Iblīs passage (2:34-36, 7:11.20, 20:116120 ), the seducer of man is referred to not by his Qur'anic name of Iblīs, but by the term ash-shaytān. This reference to the devil as ash-shayțān in the Qur'anic paradise story could be related to the fact that the Qur'anic shaytān, being a loan-word from Ephiopic with the meaning "devil," was assimilated with the authentic Arabic word shaytān, ${ }^{74}$ which was known already in pre-Islamic Arabic culture as a metaphorical name for a serpent as well as a personal name..$^{75}$ Although one should not ignore this reverberation of Biblical tradition, it should be noticed that the figure of the serpent from the garden of Eden, even if it is implied by the word ash-shaytān, is not actually found in the Qur'an. The serpent is here totally dissolved into the devil, because the Qur'anic testing story is deprived of any attracting motivations. ${ }^{76}$ Their representation, however, is the main function of the serpent motif in several works of post-Biblical literature. For example, The Cave of Treasures explains the devil's reason for using the serpent as an attempt to hide his ugliness (4:6-12). The Arabic version of this book portrays the serpent as: وكانت احمل الحيوان "And it was the most beautiful of the animals."77 The depiction of the serpent in the poem has to be seen in the context of this tradition.

Line 13 describes the serpent as "speckled," Arabic raqsha $\bar{a}^{\circ}$. In the Hebrew and Syriac texts of the Bible, the words 'ārüm and 'arim are used, respectively, meaning "crafty," "smart" (Gen. 3:1):

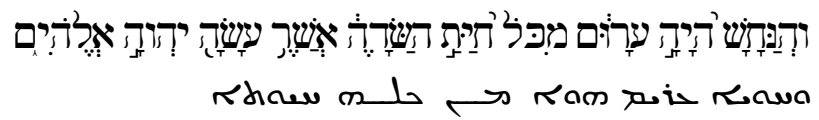

Now the serpent was more crafty than any other

71 The serpent can be found in the Qur'an only in the story of Moses and the Pharaoh. In two cases (7:107 and 26:32), the word thu'bānun is used, and only once-hayyatun (Q 20:20).

72 Toral-Niehoff, "Gestaltung des Sündenfalls," 249-251,

73 Martinek, Schlange.

74 Lane, Lexicon, 1552; compare Q 37:65 and see Renz, Schlangendrache, 96.

75 Kropp, "Der äthiopische Satan," 99-101.

76 On the demythologization of the creation account in the Qur'an and its theological meaning, see Neuwirth, "Negotiating Justice."

77 Toepel, Legenden, 143, 146, footnote 4. 
wild animal that the Lord God had made.

From the same root, ${ }^{c}-r-m$, the Hebrew word ערום ${ }^{c} \bar{a}$ rom is derived. It is differentiated in spelling from ערוּם by a single dot over the ו. 'Ārom in Hebrew means "completely or partly naked." Here, one can see a remote parallel to the meaning of the root ${ }^{c}-r-m$ in Arabic, which designates the quality of possessing two colors; this is why Arabic a ramu means "speckled." In pre-Islamic poetry, this term is used specifically in reference to serpents. ${ }^{78}$ At the same time, the Arabic verb "arama means "to be evil in disposition," "to be illnatured." ${ }^{79}$ It might therefore be suggested that raqsha ${ }^{\circ}$ is used in the poem as a synonym for $a^{c} r a m u .{ }^{80}$ This would provide further evidence for a Biblical background with which ${ }^{\mathrm{c}}$ Adī b. Zayd should have been familiar through Syriac ${ }^{81}$ tradition.

The semantics of the root $r-q$-sh in Arabic also warrant another observation. The description of the serpent as raqsh $\bar{a}^{-}$is common in pre-Islamic poetry, ${ }^{82}$ and in applying this label the poet follows conventional usage. In addition to the meaning of "black and white," the semantic field of the root $r$ - $q$-sh also includes the notion "beautiful." Raqshun is "good," "beautiful," the verb raqasha means "to color with two colors," and also "to decorate," "to embellish," and raqqasha is "to embellish speech with lies." ${ }^{83}$ Therefore, raqshä $\bar{a}^{\circ}$ conveyed not only a zoological feature, the shape of serpents, but also their beauty or ability to attract. The reading variant recorded in $\mathrm{M}^{\mathrm{P} 10}$ and $\mathrm{M}^{\mathrm{V}}$ (see the appendix), which give الرشقا "elegant," "slender," supports this assumption. Also in another poem attributed to "Adī b. Zayd the serpent of the paradise is described as both raqtāa "spreckled" and hasnā" "beautiful" ${ }^{\circ 4}$ The comparison between the serpent and the shape of a camel in line 13a is probably meant to be understood within this context.

The comparison with a camel can be interpreted in a literal as well as in a figurative sense. Literal similarity to a camel would imply the existence of legs, which are an attribute of archaic depictions of dragons. Serpentine dragons with legs are

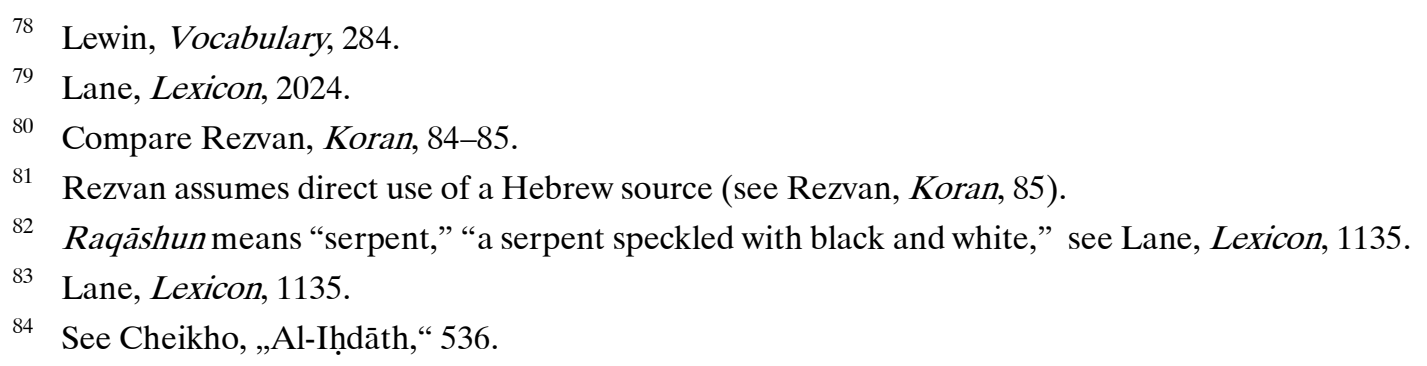


commonly found in ancient Near Eastern art. ${ }^{85}$ In the Bible, too, the serpent of paradise is identified both as a dragon and the devil (Rev. 12:9):

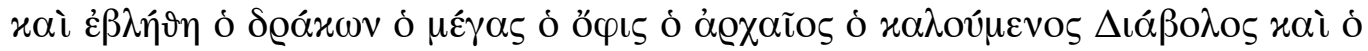

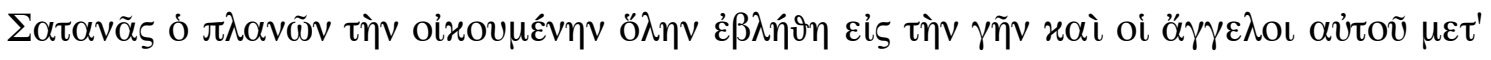

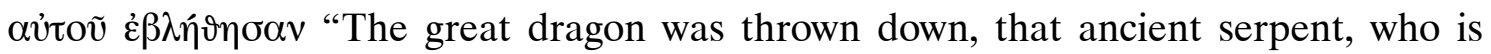
called the Devil and Satan, the deceiver of the whole world-he was thrown down to the earth, and his angels were thrown down with him." ${ }^{\prime 86}$

The notion that the serpent stood upright and had legs, found neither in the Bible nor in the Qur'an, is reflected in later exegetical tradition. ${ }^{87}$ The poet was most likely aware of this legendary material. However, the true meaning of the comparison with the camel could possibly reach beyond simple borrowing. In fact, line 13 does not say that the serpent was really (like) a camel, but just that it appeared or, more precisely, was seen in a shape similar to that of a camel. ${ }^{88}$ This nuance is also indicated through the double reference to a she-camel as well as a he-camel. Camels are often presented in pre-Islamic poetry as objects of prestige, whose appearance is considered to be beautiful and splendid. Hence, comparing the serpent to the shape of a camel could also metaphorically point to the beauty of the serpent. ${ }^{89}$

In any case, the text of the poem focuses only on the outward appearance of the serpent. Yet there is a change of perspective here, which can be observed also in other works of post-Biblical literature, where the cleverness of the serpent is replaced by its beauty. The depiction of the serpent does not just introduce a mythological creature, but serves as an illustration for the disposition of the human nature towards temptation.

85 See depictions of the Marduc dragons on the Ishtar Gate. The mythological serpent-dragon came out of the symbiosis of serpent and other animals, originally opposed to it, like birds and horses in mythologies of the post-Paleolithic era, see Ivanov, "Zmey," 468-469. For more details on the subject of the serpent of paradise, see Renz, Schlangendrache.

86 See also Rev. 20:2; in both passages, like in Gen. 3:1, the word for serpent is ó $\varphi$ ıs.

87 Already the Ethiopian Book of Enoch (10:9) attributes to the descendants of the fallen angels among other features also the shape of camels, see Toepel, Legenden, 146. For further parallels refer to Toral-Niehoff, "Gestaltung des Sündenfalls," 244-246, and Hirschberg, Lehren, 107.

88 The primary meaning of khalqun in pre-Islamic poetry is "appearance," "shape," "form," see Polosin, Slovar, 150; compare also Efim Rezvan's translation of this line in Rezvan, Koran, 84.

89 Later Islamic tradition includes references to both aspects in the depiction of the serpent of paradise, the beauty as well as the anatomy: "The snake had four feet as if it were a Bactrian camel and was one of the most beautiful animals created by God" (see The History of al-Tabarī, vol. 1, 227). 
The story thus becomes a sermon, interpreting the narrative according to its moralizing intentions. This also appears clearly in the next line.
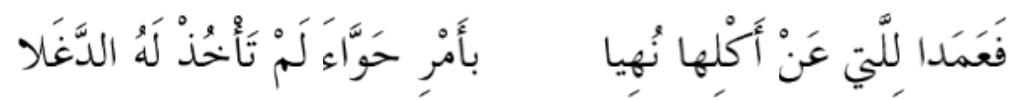

They turned to that from which they had been forbidden to eat on the order of Eve, who did not consider the evil ${ }^{90}$ in it.

The first hemistich, 14a, talks about the human couple and not about Adam and Eve

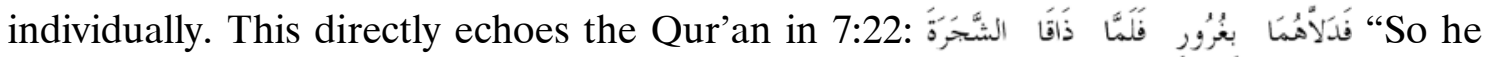
[ash-shaytān] led them on by delusion; and when they tasted the tree [....]" In the second part of line 14, however, emphasis shifts to Eve. This corresponds to the account in the book of Genesis as well as to the depiction of the fall of man in several Jewish and Christian works of Late Antiquity, where Adam's responsibility for the fall is systematically de-emphasized. ${ }^{91}$ The sharpness of the expression bi-amri Hawwāa a, "on the order of Eve," stresses her role as the protagonist of the fall and makes her appear as its actual instigator rather than the serpent or devil. ${ }^{92}$ The gender-related implication of this aspect is secondary, however, to its allegorical connotation. The latter is probably to be considered the passage's true meaning and must be viewed in the context of an ethical-allegorical interpretation of the story of the fall that is especially dominant in the Christian tradition. The serpent becomes Eve because Eve represents the principle of human sinfulness as such. ${ }^{93}$ The opening passage of the Great Canon ${ }^{94}$ of Andrew of Crete (660-740), for example, includes the following lines:

My mind's Eve took the place of the bodily Eve

for me-the passionate thought that was in my flesh.

90 The word daghalun, "rancour," "evil," "deceit" is attested in pre-Islamic poetry, but is not used in the Qur'an; see Polosin, Slovar, 163, and Lewin, Vocabulary, 130.

91 Toepel, Legenden, 155-158.

92 The identification of Eve with the serpent was rhetorically supported by pointing to the similarity of the Aramaic words חיזיא חדה Hawwā, "Eve." "serpent" andiac literature also emphasizes a

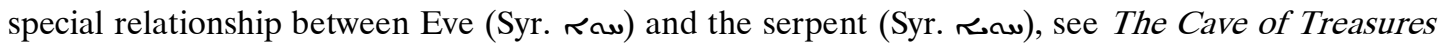

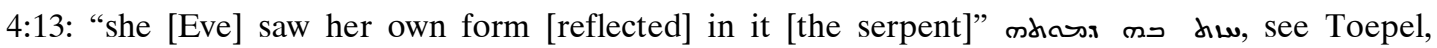
Legenden, 143, 150-151, 157.

93 Averinzev, "Poryadok," 509.

94 I:5, quoted in Amis, A Different Christianity, 43. 
Showing me the sweets

and gorging me ever on the poisonous food.

Andrew of Crete was originally from Damascus, and his liturgical poetry marks the final establishment of allegorical interpretation of Biblical history in Christian hymnography.$^{95} \mathrm{He}$ is preceded in this by earlier Christian homiletic literature, ${ }^{96}$ all of which had a clearly moralistic approach. Especially the Late Antique Syrian and Palestinian homiletic traditions were intimately linked with liturgical poetry. As Sebastian Brock points out, in the works of Ephrem the Syrian the understanding of the Biblical narrative is characterized by the author's ability "to move rapidly to and fro between the individual and the collective, between Adam and humanity as a whole."97 Thus, the homiletic character of the poem, as well as some allegorical allusions in it, provide strong evidence for the argument that it originally belonged in the literary context of Late Antique Christian tradition.

At the same time, one should note that the connection between the depiction of women and the serpent motif is also found in early Islamic Arabic poetry, as was noted by Renate Jacobi in her analysis of a poem belonging to ${ }^{\mathrm{c}} U \mathrm{mar}$ b. abī Rabī ${ }^{\mathrm{c}} \mathrm{a}$ (d. 93/712 or 103/721). ${ }^{98}$ The poet here describes his relationship with a women using the image of

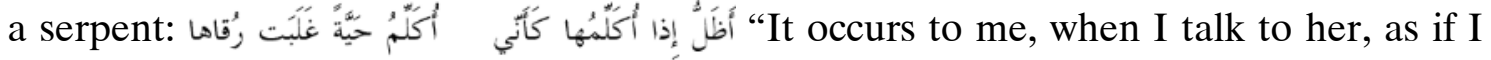
would talk to a serpent, whose charm is defeating." 99 The line obviously refers to the motifs of the paradise story. An allusion to this story in so profane a context and by a poet like ${ }^{c}$ Umar b. abī Rabī'a shows that the Eve/serpent motif and its allegorical interpretation was known in Mecca and Medina ${ }^{100}$ at least in the second half of the seventh century.

This ethical-allegorical aspect, reflected in the fusion of the motifs of the serpent and that of woman in Late Antique literature, is also dominant in the Qur'anic

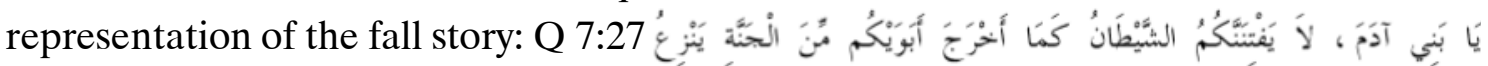
"Children of Adam! Let not Satan tempt you as he brought your parents out of the Garden, stripping them of their garments to show them their

\footnotetext{
95 Averinzev, “Poryadok," 509-510.

96 See Brock, "From Ephrem to Romanos," 146-151.

97 Brock, Hymns on Paradise, 70.

98 Jacobi, "Die Sonne auf dem Maultier."

99 Schwarz, Diwan, CCCVIII:8 (p. 225).

100 This is where ${ }^{\mathrm{c}} \mathrm{Umar}$ b. abī Rabī' ${ }^{\mathrm{c}} \mathrm{a}$ appears to have spent most of his life, see Montgomery, “c Umar b. Abī Rabīía," 822.
} 
shameful parts." The Qur'an adopts the moralistic perspective that was current in its Late Antique milieu, and replaces the symbolic aspect of Biblical mythology with the allegorical reflectiveness of a sermon. However, the Qur'an is unprecedented in the strict logicality of its allegorical approach, a feature resulting from its different theological agenda. The Qur'anic cosmogonic accounts are not presented as mythological history but as "the never-changing pattern of divine-human interaction," because their main focus is not "the memory of primordial creation of man, but the awareness of participation in a covenant concluded with Adam's offspring." 101 The Qur'anic story of the fall is a moral story integrated into the broader context of the Qur'an's theology of covenant. The Qur'an deprives the narrative of several details that are irrelevant for its basic ethical meaning. The addressees of the Qur'anic message are the "children of Adam"; in the timelessness of the allegory, they become its true subject.

The text of the poem does not greatly elaborate on this allegorical aspect. As a whole, the poem's description of the fall preserves the concreteness of its figures and is inclined towards an almost apocryphal illustrativeness. At the same time, this tendency is integrated into the homiletic framework of the poem and is accordingly colored by allegory. This unity of the literal and the allegorical is also clearly shown in the next line.

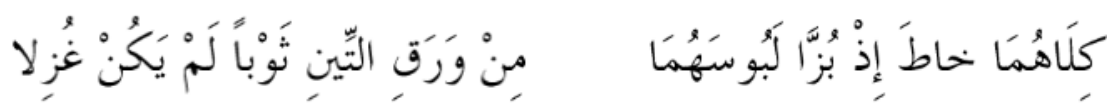

They both sewed, as their garments had been stripped off, clothing from fig leaves, which was not spun.

The notion that Adam and Eve were clothed with fig leaves after the fall is of Biblical origin. While the Qur'an only vaguely refers to "the leaves of the garden," waraqu 1jannati (Q 7:22), Gen. 3:7 clearly identifies the kind of leaf: "and they sewed fig leaves

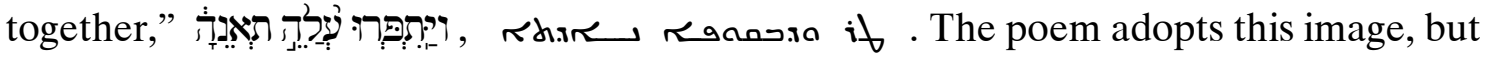
adds something new to it as well. In describing the clothing material in such a graphic way, the line creates an implicit contrast to the original garments of mankind. In opposition to the evidence of Gen. 2:25 ("And the man and his wife were both naked,

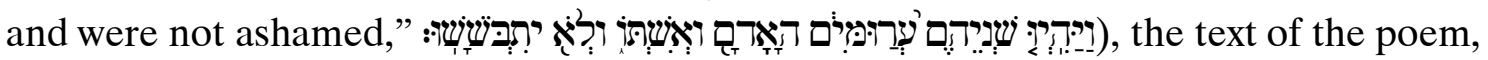
as well as that of the Qur'an (7:27), implies that Adam and Eve were dressed prior to the fall. The nature of their garments, however, is not explained. Yet the idea that man was clothed in paradise even before the fall is reflected in earlier traditions in which

101 Neuwirth, “Negotiating Justice,” 16. 
these clothes are described as light and glory and by similar metaphors. In Syriac literature, the motif of clothes of light is attested since the time of Ephrem. ${ }^{102}$ It is therefore likely that labūsun in line 15 is figurative in meaning. The Qur'an also speaks of the clothes of man $(7: 26)^{103}$ and extends their moralistic function to bodily clothes, which, as "one of God's signs," are to remind man to dress himself with the "garments of the God-fearing."
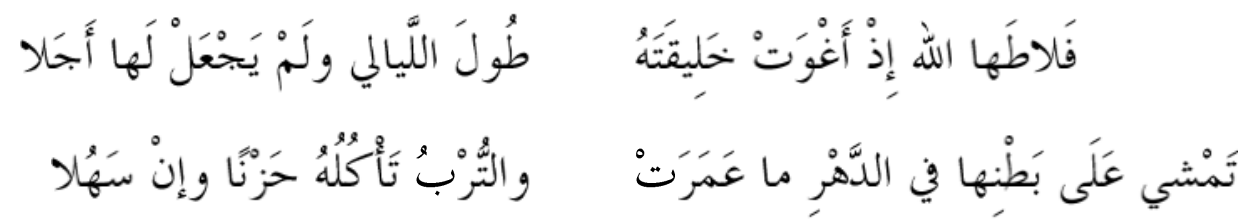

God cursed it because it has seduced his creation, for all times and he did not set a term for it.

It goes on its belly (all) time as long as it lives, and dust - it eats it as hard ground even when it is soft.

A Biblical parallel to the punishment of the serpent can be found in Gen. 3:14-15. ${ }^{104}$ The notion of God setting a term, however, is a motif that unfolds only in post-Biblical literature. Both The Testament of Adam ${ }^{105}$ and The Cave of Treasures, ${ }^{106}$ among other texts, mention a temporal limitation placed on humanity's exile on earth and the time remaining until salvation. God's setting of a limit here is a motif of consolation. It might be added that, according to the Qur'an, God sent people down to earth "only for a time" (Q 2:36). The concept of salvation does not appear in the Qur'an, as it does not subscribe to the idea of original sin. Qur'anic eschatology, however, is closely related to the expediency of creation and divine predetermination. The word ajalun, "deadline," "time limit," is employed frequently, and is also used to refer to the end of time (29:53). ${ }^{107}$ What is remarkable is the universal character of the Qur'anic idea of this time

\footnotetext{
102 On this motif in The Caves of Treasures, see Toepel, Legenden, 159.

103 See Neuwirth, "Qur’ān, Crisis and Memory," 142.

104 The verb mashaya, "to go," in line 17a corresponds exactly with the wording of Gen. 3:14, both in Hebrew and Syriac.

105 Robinson, The Testament, 58-63.

106 Toepel, Legenden, 144, 164-166.

107 On ajalun in the Qur'an, see Speyer, Die biblischen Erzählungen, 3. The noun ajalun, as well as other derivations of the root $a-j-1$, are found in several pre-Islamic sources, see Polosin, Slovar, 29, and
} 
limit. Nothing will remain on earth beyond this point. Even the Devil is damned until the Day of Doom and is "among the ones that are respited unto the day of a known time" (Q 15:35-38). By contrast, according to the poem the fate of the serpent is sealed by the denial of any such term, which implies an immediate and irrevocable judgement. The shift from the setting of a time limit to its explicit rejection can also be traced in Jewish sources. ${ }^{108}$ The Syriac theological tradition of Aphraat and Ephrem endores the view that only common sinners will attend the Last Judgment, whereas great sinners will be banished right after the resurrection into the hell. ${ }^{109}$ Also, the meaning of the Hebrew

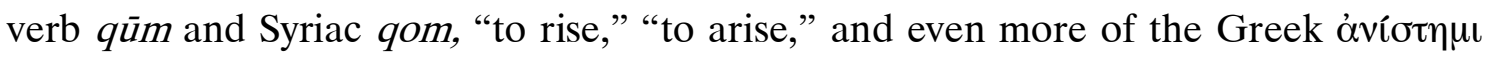
and Latin resurgo in Ps. 1:5 $5^{110}$ express the notion that the wicked will not rise for judgment. Psalm 1, one of the central texts of Christian liturgy that was also prominent in the Syriac tradition, thus ought to be considered as one of the poem's intertexts. Syriac background can also be seen in the next line.
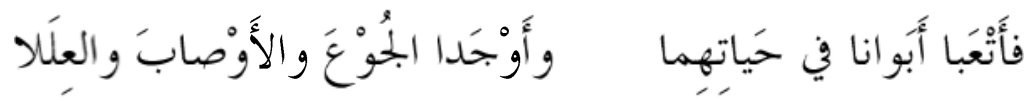

Our parents became tired in their life

and they caused hunger, continual pains and vices.

The description of the punishment is reminiscent of the Biblical account. According to Gen. 3:14-19, only the serpent and the earth were directly cursed by God, whereas Adam and Eve were only punished with hardship. ${ }^{111}$ The poem adopts the same

Lane, Lexicon, 24f. In their original semantics, they evoke the liquidation of debts. This meaning is also evident in Q 2:282, where ajalun expresses a certain time limit for a debt contract. Also, the idea of determination of a lifetime probably already existed in pre-Islamic Arabic culture (see Montgomery Watt, "Adjal”), which was characterized by a strongly fatalistic perception of fate (see Caskel, Das Schicksa). This may have been adopted and reinterpreted in early Islam, see Dmitriev, Abū Ṣahr al-Hudalī, 105-128.

108 Genesis Rabbah 20:5; Midrash Tehillim 1:10; cf. Hirschberg, Lehren, 108.

109 Frolovskiy, Wostochniye otzy, 225, 232.

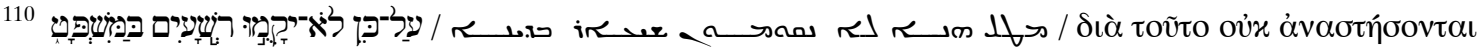

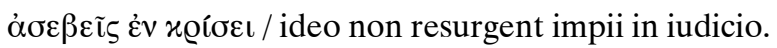

111 Compare The Cave of Treasures 5:2-4: „God spake unto Adam, and heartened him, and said unto him, 'Be not sorrowful, O Adam, for I will restore unto thee thine inheritance. Behold, see how greatly I have loved thee, for though I have cursed the earth for thy sake, yet have I withdrawn thee 
differentiation and further de-emphasizes the damnation of man in relation to God's role as punisher as well as the measure of man's penalty. Along with pointing to the difficult conditions of earthly life, the book of Genesis clearly indicates the perspective of death (Gen. 3:19). This is not explicitly expressed in the verse above. To be sure, hunger, pains, and vices are symbols of death, yet death itself is not mentioned. Moreover, the punishment is neither declared by God nor does it immediately befall mankind. Instead, "our parents" are represented as carrying out their sentence by themselves. Both verbs, at ${ }^{c} a b a$, "to become tired," and awjada, "to cause," "to bring into being," are used actively. Thus, the responsibility for the men's suffering, and with it for the evil in general, is completely removed from God. This is also indicated by the character of the punishment. All three words-jūcun, "hunger," awșābun, "continuous pains," 112 and ilalun, "defects," event of punishment. Adam and Eve appear as the cause of punishment because they negatively changed their mode of living, and thus burdened their lives with "toil" for as long as it lasts (Gen. 3:17). This serves, however, not just to defend the divine attribute of goodness, but also to show the relationship between God and humans in a positive light. The poem does not go so far as to narrate God's consolation of Adam that can be found in the Qur'an (2:37-38). However, the poem clearly downplays the irrevocability of the expulsion from paradise that is implied in Gen. 3:22-23 and leaves open the possibility of salvation. This transformation of the punishment is characteristic of the Christian post-Biblical tradition and is documented, for example, by the Syriac Cave of Treasures (5:3). ${ }^{114}$ The parallel becomes obvious in the following lines.

from the operation of the curse." See The Book of the Cave of Treasures, 67, and Toepel, Legenden, 144.

112 Continual, or constant pain, or emaciation of the body by reason of fatigue or disease or excessive fatigue, see Lane, Lexicon, 2944-2945.

113 According to Lane, Lexicon, 2124 cillatun, pl. cilalun means: "An accident that befalls an object and causes its state, or condition, to become altered. [...] a disease that diverts [from the ordinary occupations; [...] An accident, or event, that diverts the person to whom it occurs from his course."

114 Its comparison with the Qur'anic account of Adam's consolation see Toepel, Legenden, 168-169. 
Epilog (vv. 19-20)
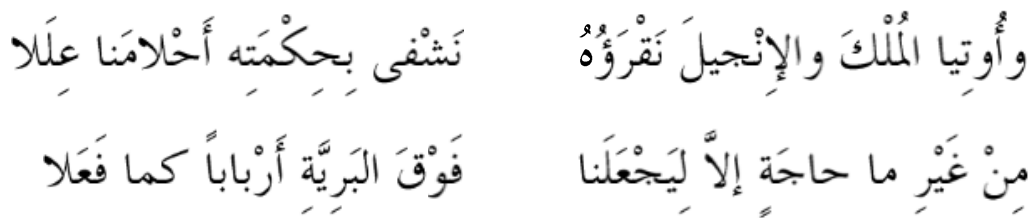

They were given the kingdom and the Gospel that we read.

We cure with its wisdom our mental powers and vices,

Without him having any need except for making us

lords over his creation as he made (it).

The dialogical framework of the poem becomes evident once again in the closing passage, which from the first to the last line sets up a rhetorical curve of suspense. The question implied refers to whether creation, especially the creation of man, was after all an advisable thing to do. The answer given in the poem is based on fundamental concepts of Christian anthropology, such as the sinful nature of man and the necessity of salvation. In Christian theology, these two concepts are inseparable linked. Again, the allegorical parallelism of creation and salvation comes to light. According to the Syriac Cave of Treasures, not only was Adam granted after his creation "the power over everything which I [God] created" (2:19), ${ }^{115}$ but after the Fall "God revealed unto Adam everything which the Son would suffer on behalf of him" (5:13). ${ }^{116}$ Adam's power realizes itself only through the Gospel, ${ }^{117}$ and the purpose of creation is fulfilled only in the Gospel-a perspective of salvation in which death is already overcome, and which could only be thus expressed by a Christian author.

115 The Book of the Cave of Treasures, 53; see also Toepel, Legenden, 57.

116 The Book of the Cave of Treasures, 67; see also Toepel, Legenden, 144.

${ }^{117}$ Horovitz considers the word injillun an indication that the line is a later forgery, since according to him injillun is a loan-word form Ethiopic unlikely to have been used in Mesopotamia at such an early time (see Horovitz, Untersuchungen, 71, and also Toral-Niehoff, "Gestaltung des Sündenfalls," 248-249). However, the early borrowing of such a central theological term as "Gospel" appears plausible if one takes into consideration that Arabic had been a vehicle for Christian thought probably from as early as the fourth century CE (see Shahid, Byzantium, 744). Also, as pointed out by Meir Kister, relations between al-Hīra and the Arabian Peninsula in pre-Islamic times were much more vigorous than has previously been assumed (see Kister, "Al-Hīra"). Thus, an early transmission of the word injillun into Mesopotamia is quite possible. 


\section{Conclusion}

Textual and literary analysis lead to the conclusion that the present poem was originally composed in a Christian milieu. Neither the literary nor the historical/theological context supports arguments against the early origin of the text and its composition by a Christian author like ${ }^{c}$ Adī b. Zayd. In only a very few cases do Islamic connotations allow for the assumption of direct dependence on Islamic sources. As can be seen by the use of the word khalifatun in a version of line 16, this occurred due to the poem's later transmission. Similarities with Qur'anic accounts of the story of creation and the fall are due to a shared thematic basis, as well as to a shared tendency to interpret it allegorically within a broadly homiletic framework. On the other hand, the evident differences on the theological level clearly show that the text of the poem cannot be viewed as dependent on the Qur'an. This, however, does not make it less relevant. The Qur'an is very selective in its adoption of Biblical tradition, and the reconstruction of this tradition in its pre-Islamic environment can significantly contribute to our understanding of the logic of its transformation in the Qur'an. In contrast to the Bible, the Qur'anic stories of creation and paradise are not comprehensive chronological reports, but are evoked in a number of separate passages with clear hermeneutical implications. The admonitory intention of the relevant Qur'anic texts is striking. The Qur'an is less concerned with the narration of history than with presenting its ethically relevant message. It does not explain something absolutely new to its audience, but tries instead to draw out the moral of something already known. Thus, the Qur'anic message does not unfold in a silent vacuum, but rather in communicative reference to its rich and diverse background. From this point of view, texts like the poem presented, which might provide an insight into the religious background of the Arabs prior to the rise of Islam, are indispensable for the historical-critical study of the Qur'an. 


\section{Appendix 1: Sources}

The main sources that transmit longer passages of the poem in coherent form are (in chronological order):

H Jạhị, Kitāb al-ḥayawān, vol. 4, 65-66 (ninth century).

Eleven lines from the second part of the poem, corresponding to line 8 and lines 10 through 20 of the compiled text. This work can be found below.

Mq Al-Maqdisī, Kitāb al-bad ${ }^{\circ}$ wa-t-ta ${ }^{\circ}$ rīkh, vol. 1, 151 (tenth century).

Contains seven lines from the poem's first section, lines 1 through 6 and line 8 .

AM Abū al- ${ }^{\mathrm{c}} \mathrm{Ala}^{\mathrm{j}}$ al-Ma ${ }^{\mathrm{c}}$ arrī, Risāla, 264-265 (eleventh century).

Quotes thirteen lines, equivalent to lines 1 through 4, 6 through 10, 12 to 13 and lines 16 and 17.

M Al-Maqrīzī, Al-mawā ${ }^{c}$ iz, vol. 1, 86-87 (fifteenth century).

Fifteen lines, consisting of lines 1 through 13 and 16 to 17.

The attestation of individual lines in these main sources can be represented as follows:

\begin{tabular}{|c|c|c|c|c|}
\hline Line & \multicolumn{4}{|c|}{ Source } \\
\hline 1 & & $\mathrm{Mq}$ & AM & $\mathrm{M}$ \\
\hline 2 & & $\mathrm{Mq}$ & AM & $\mathrm{M}$ \\
\hline 3 & & $\mathrm{Mq}$ & AM & $\mathrm{M}$ \\
\hline 4 & & $\mathrm{Mq}$ & AM & M \\
\hline 5 & & $\mathrm{Mq}$ & & $M$ \\
\hline 6 & & $\mathrm{Mq}$ & AM & $M$ \\
\hline 7 & & & AM & M \\
\hline 8 & $\mathrm{H}$ & $\mathrm{Mq}$ & AM & M \\
\hline 9 & & & AM & $\mathrm{M}$ \\
\hline 10 & $\mathrm{H}$ & & AM & $\mathrm{M}$ \\
\hline 11 & $\mathrm{H}$ & & & M \\
\hline 12 & $\mathrm{H}$ & & AM & $\mathrm{M}$ \\
\hline 13 & $\mathrm{H}$ & & AM & $\mathrm{M}$ \\
\hline 14 & $\mathrm{H}$ & & & \\
\hline 15 & $\dot{\mathrm{H}}$ & & & \\
\hline 16 & $\dot{\mathrm{H}}$ & & AM & $\mathrm{M}$ \\
\hline 17 & $\dot{H}$ & & AM & M \\
\hline 18 & H & & & \\
\hline 19 & $\mathrm{H}$ & & & \\
\hline 20 & $\mathrm{H}$ & & & \\
\hline
\end{tabular}


Lines 1, 5 and 6 are transmitted in isolation in the following sources:

Line 1 T Tha ${ }^{\mathrm{c}}$ lab, Kitāb al-Majālis, vol. 1, 127.

Az Al-Azharī, Tahdhīb al-lugha, vol. 10, 412.

An An-Anbārī, Al-inșāf, 244.

B $\quad{ }^{\mathrm{c}}$ Abd al-Qādir b. ' Umar al-Baghdādī, Khizāna, vol. 10, 224.

LA Lisān, vol. 15, 233, 236.

Line 5 TA Tāj, vol. 3, 542, LA (mṣr)

Line 6 F Ibn Fāris, Maqāyīs al-lugha, vol. 5, 330.

RI Ar-Rāghib al-Iṣfahānī, Al-mufradāt, 469.

Z Az-Zamakhsharī, Asās al-balagha, vol. 2, 389.

Bd Ibn al-Faqīh al-Hamadhānī, Mukhtașar kitāb al-buldān, 57.

Y Yāqūt, $\mathrm{Mu}^{\mathrm{c}}$ jam al-buldān, vol. 1, 42.

TA and LA (msr)

References in the main sources display vast differences in scope. However, they overlap at several points and exhibit a stable sequence of verses within each quoted passage. This indicates the constant transmission of a common source and allows us to arrange the individual passages into a whole. 
Appendix 2: Text

Basìt
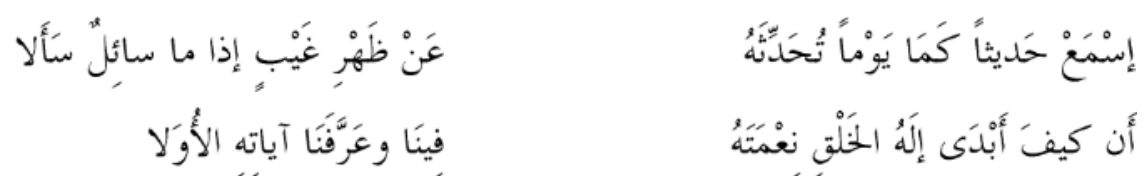

1. Az, AM, An, $M^{118}$

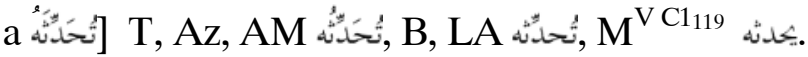

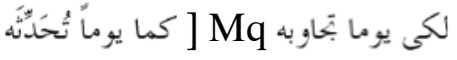

Al-Maqrīzī (M) attributes the line also to Umayya b. abī aṣ-Ṣalt.

2. $\mathrm{Mq}$

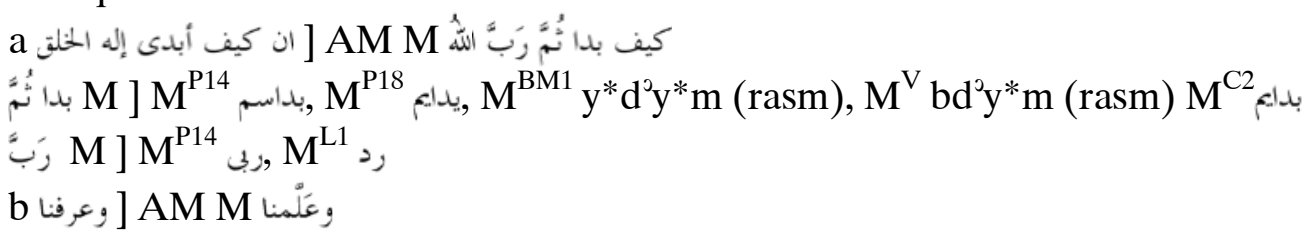

118 The first line of the poem is the one that is most amply documented. The reason for this is the special usage of the conjunction ka-mã found here. Here it has the meaning "so that" and is equivalent to the common conjunction kaymā (see WKAS, vol. 1, 9). This is specific to the Kufic grammatical school, and the line is often quoted by Arabic philologists as a reference for it (T, Az, An, B, LA). This linguistic peculiarity also indicates that the line was originally composed in the region of Kufa, to

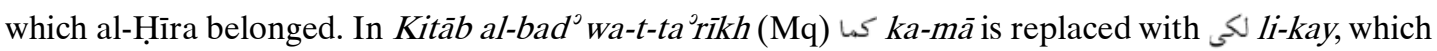
more unequivocally introduces a final clause. The first part of the poem is cited by al-Maqdisi in a long chapter on the creation of the world, where the focus is on the poem's content rather than its linguistic features. It should also be borne in mind that Mq was written in Afghanistan (ca. 355/966). This makes the replacement of a specifically Kufic form with a commonly valid and unmistakable reading quite plausible. The version with لكى li-kay should therefore not be considered as an inaccurate reproduction of the original, but rather as indirect evidence for the fact that the poem was known in wider circles than simply among philologists. On the other hand, the frequent citation of this line in an exclusively linguistic context does not betray any motivation for forgery, and therefore supports its authenticity.

${ }^{119}$ Superscripts following the symbol $\mathrm{M}$ correspond to the manuscripts used in the edition of Gaston Wiet (see al-Maqrīzì, $A l-m a w a ̄ c i z)$. 

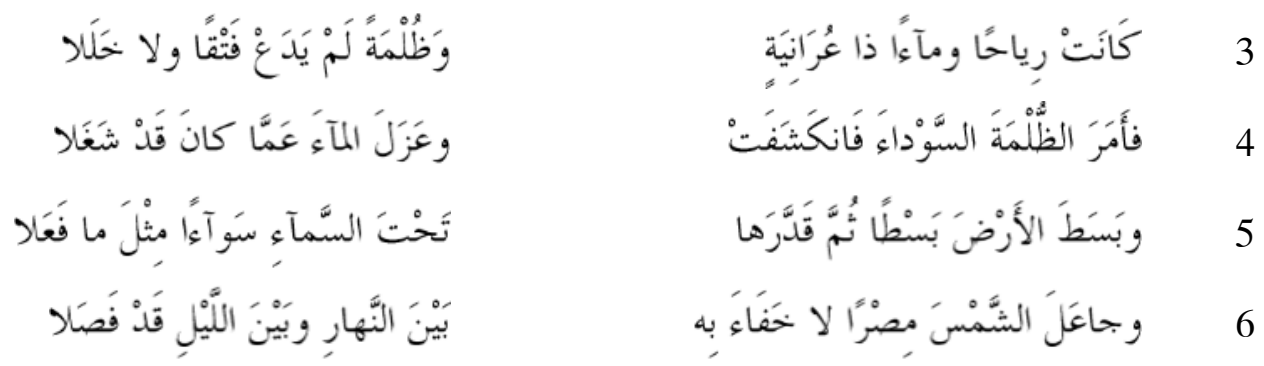

3. $\mathrm{Mq}$

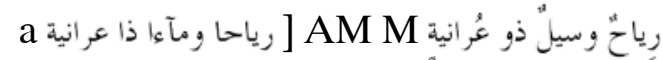

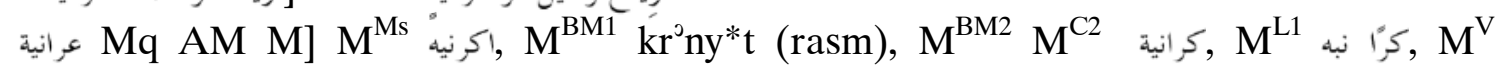
$\mathrm{kr}^{3} \mathrm{n}^{*} \mathrm{y}^{*} \mathrm{t}^{*}$ (rasm)

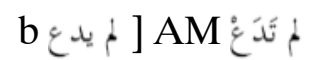

4. Mq, M

الظمم السواد $\mathrm{M}^{\mathrm{C} 2}$

و مسير

5. $\mathrm{Mq}$

وَالأرضَ سَوّى بساطاً TA LA و وبسط الأرض بسطآ

b السوا السمآ

سوى سو آء $M^{\mathrm{P} 9}$ سوآءأ

ميل

ثققلا TA LA نقلا M فيلا

6. F, Y

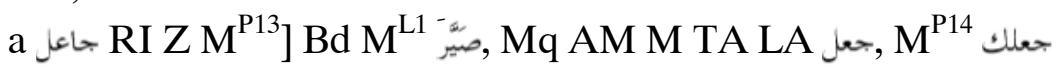

النمس cons. ] M

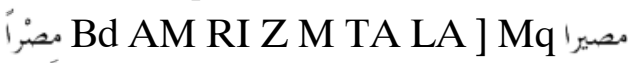

b بين النهار وبين الليلَ cons. ] M M14 من النهار ومنه الليل

مذ قد cons. ] Mد

فضال Bd AM RI Z TA LA ] Mصلا

RI quotes the line anonymously; TA and LA attribute lines 5 and 6 to Umayya b. abī aṣȘalt; note, however, that according to Ibn Barrī, these lines are composed by ${ }^{\mathrm{c}}$ Adī $b$. Zayd. $\mathrm{M}$ mentions that line 6 is written by ${ }^{\mathrm{c}} \mathrm{Adi} \mathrm{b}$ b. Zayd, but has also been attributed to Umayya b. abī aṣ-Șalt. 


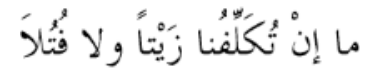

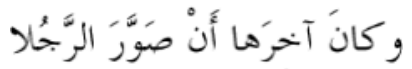

$$
\begin{aligned}
& \text { حتى إذا ما رآه تَمَّ واعتدَلاً }
\end{aligned}
$$

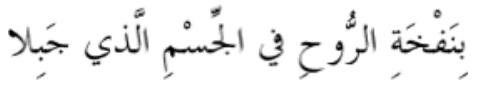

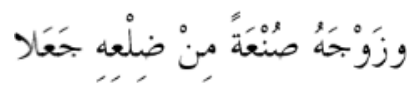

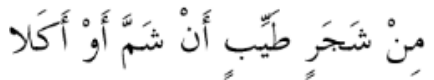

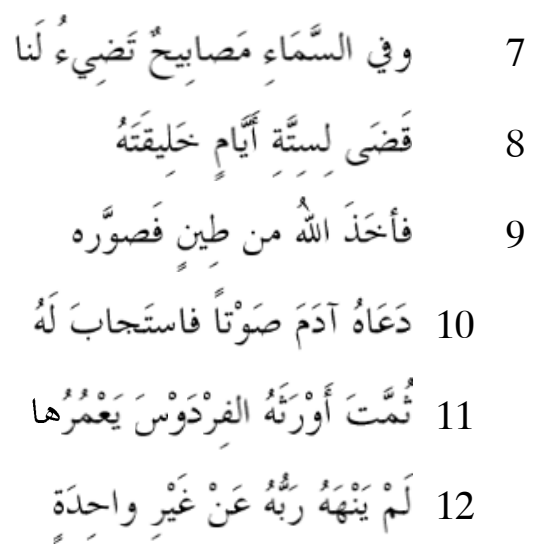

$7 \mathrm{AM}$

المساء

تُضى

أن إن M (the nagative in, see Wright, Grammar, vol. 2, \$158, 301) [

8. H

خحائقه H AM M] خليقته

b آخر شىء

9. AM

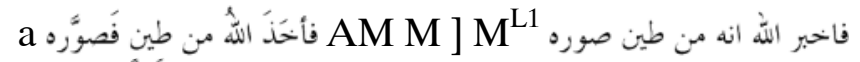

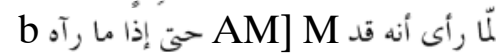

سم

10. $\mathrm{H}$

فنفخ الروح

11. $\mathrm{H}$

$\mathrm{a}$ M $\mathrm{M}] \mathrm{M}^{\mathrm{BM1}} \mathrm{y}^{*} \mathrm{mt}$ (rasm), $\mathrm{M}^{\mathrm{C} 2}$

اورثنه أو أورته

يسكنه

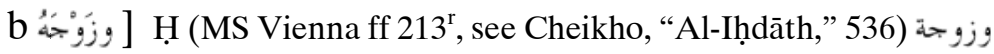

ضلعة من جنبة M [ صنعةً من ضلعه

فعلا

12. H M

b إن إن 


$$
\begin{aligned}
& \text { كما تَرَى ناقَة في الْخَلْقَ أو جَمَلا }
\end{aligned}
$$

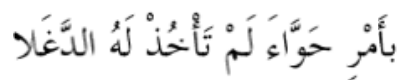

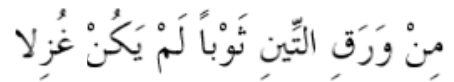

$$
\begin{aligned}
& \text { طُولَ اللَّالِي ولَمْ يَجْعَلْ لَها أَجَلا } \\
& \text { والتُرْبُ تَأُكُلُهُ حَزْنَا وإنْ سَهُلا }
\end{aligned}
$$

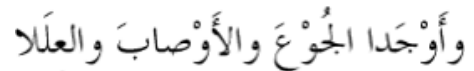

$$
\begin{aligned}
& \text { نَشْفَى بِحِكْمَته أَحْلامَنا عِلَال } \\
& \text { فَوْقَ البرَيَّة أَرْباباً كما فَعَلا }
\end{aligned}
$$

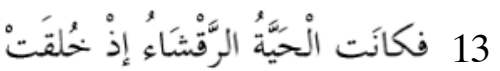

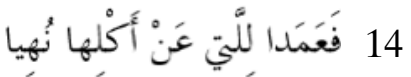

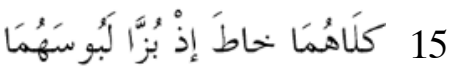
16

17

18

19

20

13. H, AM, M

a الحمنة الحنة

b الرقشاء الرشقا M

14. $\mathrm{H}$

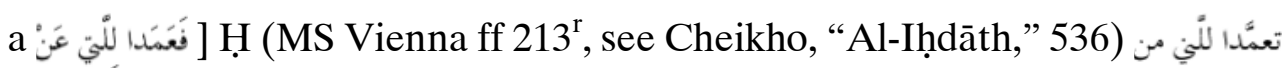

15. H

16. $\mathrm{H}$

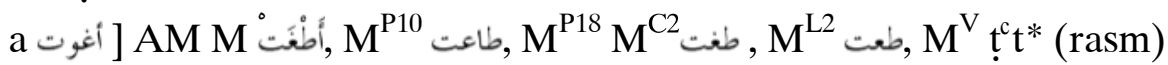

حليبته خلحليفته

17. $\mathrm{H}$

في الأرض AM M

18. $\mathrm{H}$

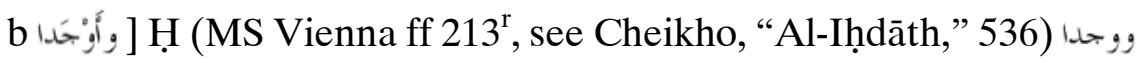

19. H

20. H 
Bibliography

'Abd al-Qādir b. ${ }^{c}$ Umar al-Baghdādī. Khizānat al-adab wa-lubb lubāb lisān al- ${ }^{c} a r a b$. Vol. 10. Cairo, 1982.

Abrahamov, Binyamin. "Signs." In Encyclopaedia of the Qur ān, vol. 5, 2-11. Leiden, 2006.

Abū al- ${ }^{\mathrm{c}} \mathrm{Alā}{ }^{\circ}$ al-Ma ${ }^{\mathrm{c}}$ arrī, Aḥmad b. ${ }^{\mathrm{c}} \mathrm{Abd}$ Allāh b. Sulaymān. Risālat aṣ-șāhil wa-shshāḥij. Edited by ${ }^{\mathrm{c}} \overline{\mathrm{A}}^{\mathrm{i} i s h a}{ }^{\mathrm{c}} \mathrm{Abd}$ al-Raḥmān Bint ash-Shāṭi'. Cairo, 1974.

Ahlwardt, Wilhelm. The Divans of the six ancient Arabic poets Ennābiga, 'Antara, Tharafa, Zuhair, 'Alqama und Imruulqais. London, 1870.

Aghānī. Abū al-Faraj al-Iṣfahānī. Kitāb al-aghānī. 20 vols. Būlāq, 1285 (AH).

Aphraatis sapientis persae demonstrations. Edited by Johannes Parisot. Paris, 1894.

Amis, Robin. A Different Christianity: Early Christian Esotericism and Modern Thought. New York, 1995.

al-Anbārī, Abū al-Barakāt. Al-inșāf fì masāòil al-khilāf an-naḥwiyyīn al-bașriyyīn wa-lkufiyyin. Edited by Gotthold Weil. Leiden, 1913.

Aphraates. The homilies of Aphraates, the Persian sage. Edited by William Wright. London, 1869.

Arberry, Arthur J. The Koran interpreted. 2 vols. London, 1955.

Asmus, Mikhail V. "Tvorchestvo Romana Sladkopevza (kon. V v. - ok. 560 g.)" [Russ.: "Works of Romanos Melodus (end of the 5th cent. - ca. 560)."] In Westnik Rossiyskogo Gumanitarnogo Nauchnogo Fonda 3 (2000): 189-200.

Attalah, W. “Al-Kalbī.”In Encyclopaedia of Islam, new edition, vol. 4, 494-496. Leiden, 1978.

Averinzev, Sergey S. "Poryadok kosmosa i porjadok istorii" [Russ.: "The order of the cosmos and the order of history"]. In Augustin: pro et contra, 487-513. Saint Petersburg, 2002.

al-Azharī, Abū Manṣūr Muḥammad b. Aḥmad b. Azhar. Tahdhīb al-lugha. Vol. 10. Cairo, 1967.

Baumstark, Anton. "Arabische Übersetzung eines altsyrischen Evangelientextes und die Sure 21105 Zitierte Psalmenübersetzung.” In Oriens Christianus 9 (1934): 165188.

Beck, Edmund. “Des Heiligen. Ephräm des Syrers Hymnen De Fide. Louvain, 1955.

Brock, Sebastian P. "Syriac Dispute Poems: The Various Types." In Dispute poems and dialogues in the ancient and medieval Near East: forms and types of literary debates in Semitic and related literatures, edited by Gerrit J. Reinink, 109-119. Leuven, 1991. Brock, Sebastian P. Hymns on Paradise. Crestwood, 1990. 
Brock, Sebastian P. "From Ephrem to Romanos.” In Studia Patristica 20 (1989): 139_ 151.

Beeston, Alfred F.L. "Antecedents of Classical Arabic Verse?" In Festschrift Ewald Wagner. Vol. 1, Semitische Studien unter besonderen Berücksichtigung der Südsemitistik, edited by Wolfhart Heinrichs and Gregor Schoeler, 234-243. Beirut, 1994.

Caskel, Werner. Lihyan und Lihyanisch. Cologne, 1954.

Caskel, Werner. Das Schicksal in der altarabischen Poesie: Beiträge zur arabischen Literatur und zur allgemeinen Religionsgeschichte. Leipzig, 1926.

Cheikho, Luis. "Al-Iḥdāth al-kitābiyya fĩ shu'arā̄ al-jāhiliyya.” In: al-Mashriq 7 (1904), 530-539.

Clementis Romani Epistolae binae de Virginitate. Edited by Joannes Th. Beelen. Louvain, 1856.

Comneno, Maria A.L. "Nestorianism in Central Asia during the First Millennium: Archeological Evidence." Journal of the Assyrian Academic Society11 (1997), 22-53.

Dīwān 'Adī b. Zayd. Edited by Jabbār M. al-Mu aybid. Baghdad, 1965.

Dmitriev, Kirill. Das poetische Werk des Abū Șahr al-Hudalī. Eine literaranthropologische Studie. (Forthcoming).

Dziekan, Marek M. Quss Ibn Sã̄ida al-Iyādī. Legenda życia i twórczości [Pol.: Quss Ibn Sācida al-Iyādī. The legend of life and works]. Warsaw, 1996.

Endress, Gerhard. "Arabische Schrift.” In Grundriss der arabischen Philologie. Vol. 1, Sprachwissenschaft, edited by Wolfdietrich Fischer, 165-183. Wiesbaden, 1982.

Frolovskiy, Georgiy. Wostochniye otzy IV veka [Russ.: Eastern Church fathers of the 4th century]. ${ }^{2}$ Moscow, 1992.

Gabrieli, Francesco, “Adī b. Zaid, il poeta di al-Ḥīrah.” In Atti della accademia nazionale dei Lincei 3 (1948): 81-96.

Greenstein, E.L. "God's Golem: The Creation of the Human in Genesis 2." In Creation in Jewish and Christian Tradition, edited by Henning Graf Reventlow and Yair Hoffmann, 219-239. London/New York, 2002.

Grünebaum, Gustav von. "Pre-Islamic Poetry." The Moslem World 32 (1942): 147-153.

Grünebaum, Gustav von. "Zur Chronologie der früharabischen Dichtung.” Orientalia 8 (1939): 328-345.

Hainthaler, Theresia. " $A d \bar{i}$ ibn Zayd al- ${ }^{\mathrm{C}}$ Ibādī, the Pre-Islamic Christian Poet of alHīrā and his Poem Nr. 3 written in Jail.” Parole de l'Orient 30 (2005): 157-172.

Hirschberg, Joachim W. Jüdische und christliche Lehren im vor- und frühislamischen Arabien. Ein Beitrag zur Entstehungsgeschichte des Islam. Cracow, 1939. 
Hirschberg, Joachim W. Der Dīwān des as-Samau al Ibn ' 'Ādijā̃ . Cracow, 1931.

Horovitz, Joseph. " Adī ibn Zeyd, the Poet of Hira.” Islamic Culture 4 (1930): 31-69.

Horovitz, Joseph. Koranische Untersuchungen. Berlin and Leipzig, 1926.

Ibn al-Faqīh al-Hamadhānī. Mukhtaṣar kitāb al-buldān (Compendium Libri Kitāb alBoldān). Edited by Michael Jan de Goeje. Leiden, 1885.

Ibn Fāris, Abū al-Husayn Aḥmad b. Fāris b. Zakariyyāo . Maqāyīs al-lugha. Vol. 5. Cairo, 1972.

Ivanov, W.W. "Zmey" [Russ.: Serpent]. In Mify narodov mira [Russ.: Myths of the peoples of the world], vol. 1, 468-471. Moscow, 1988.

Jacobi, Renate. "Die Sonne auf dem Maultier ' Umar ibn Abī Rabīia als Humorist." In Humor in der arabischen Kultur. Edited by Georges Tamer. Berlin/New York, 2008. (Forthcoming).

Jāḥiz, Abū ' Uthmān b. Baḥr. Kitāb al-ḥayawān. Vol. 4. Cairo, 1906.

Jeffery, Arthur. The Foreign vocabulary of the Qur'an. Baroda, 1937.

Kister, Meir. J. "Al-Hīra. Some notes on its relations with Arabia." In Arabica 15 (1968): 143-169.

Kropp, Manfred. "Der äthiopische Satan = šaytān und seine koranischen Ausläufer; mit einer Bemerkung über verbales Steinigen.” In: Oriens Christianus 89 (2005): 91102.

Lane, William E. Arabic-English Lexicon. Vols. 1,1-8. London, 1863-1893.

Lewin, Bernhard. A Vocabulary of the Hudailian Poems. Göteborg, 1978.

Lisān: Jamāladdīn Abū al-Faḍl Muḥammad b. Manẓūr al-Ifrīqī. Lisān al- ${ }^{c} a r a b .15$ vols. Beirut, 1955.

Al-Maqdisī, Muṭahlar b. Țāhir. Kitāa al-bad ${ }^{\circ}$ wa-ta ${ }^{\top}$ î̉kh. Edited by Cl. Huart. Vol. 1. Teheran, ${ }^{2} 1962$.

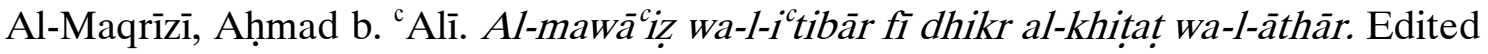
by Gaston Wiet. Vol. 1. Cairo, 1911.

Martinek, Manuela. Wie die Schlange zum Teufel wurde. Die Symbolik in der Paradiesgeschichte von der hebräischen Bibel bis zum Koran. Wiesbaden 1996.

al-Mawsü $\bar{u}^{c}$ a Abu Dhabi 2003.

Monneret de Villard, Ugo. Le chiese, della Mesopotamia. Rome, 1940.

Montgomery, James E. "“Umar b. Abī Rabīa a." In Encyclopaedia of Islam, new edition, vol. 10, 822-823. Leiden, 2000.

Montgomery Watt, William. “Adjal.” In Encyclopaedia of Islam, new edition, vol. 1, 204. Leiden, 1960. 
Neuwirth, Angelika. "Qur̄ān, Crisis and Memory. The Qur'ānic path towards canonization as reflected in the anthropogonic accounts." In Crisis and Memory in Islamic Societies, edited by Angelika Neuwirth and Andreas Pflitsch, 113-152. Beirut, 2001.

Neuwirth, Angelika. "Negotiating Justice: A Pre-Canonical Reading of the Qur'anic Creation Accounts.” In Journal of Qur'anic Studies 1 (1999): 25-41, and 2 (2000): 118.

O'Shaughnessy, Thomas. "Creation from Nothing and the Teaching of the Qur'ān." In Zeitschrift der Deutschen Morgenländischen Gesellschaft 120 (1970): 274-280.

Payne Smith, Robert. Thesaurus Syriacus. 2 vols. Oxford, 1879-1901.

Payne Smith, Robert. Syriac Dictionary. Oxford, 1903.

Polosin, Vladimir V. Slovar poetov plemeni ${ }^{c}$ abs (VI-VIII VV.) [Russ.: A Vocabulary of ${ }^{c}$ Absite Poets ( $\sigma^{\text {th }} / \delta^{\text {th }}$ cent.)]. Moscow, 1995.

ar-Rāghib al-Iṣfahānī, Abū al-Qāsim al-Ḥusayn b. Muḥammad b. al-Mufaḍḍal. Almufradāt fì gharīb al-qurō̄n. Cairo 1961.

Rezvan, Efim A. Koran i ego mir [Russ.: The Qur'an and its world]. Saint Petersburg, 2001.

Renz, Barbara. Der orientalische Schlangendrache. Ein Beitrag zum Verständnis der Schlange im biblischen Paradies. Augsburg, 1930.

Robinson, Stephen E. The Testament of Adam. An Examination of the Syriac and Greek Traditions. Chico, 1982.

as-Sațlī, 'Abd al-Hafiz. ' Umayya b. abī aș-Salt. Damascus 1974.

Schwarz, Paul. Der Diwan des ${ }^{c}$ Umar Ibn Abi Rebica. Leipzig, 1901.

Shahid, Irfan. Byzantium and the Arabs in the Sixth Century. Vol. 1. Part 2: Ecclesiastical History. Washington D.C., 1995.

Shahid, Irfan. "Al-Hīra." In Encyclopaedia of Islam, new edition, vol. 3, 462-463. Leiden, 1967.

Sefer Pirqe d Rabbi Eliezer. Edited by A.A. Broda. Tel Aviv, 1961-1963.

Seidensticker, Tilman. "The Authenticity of the Poems ascribed to Umayya Ibn Abì alSalt.” In Tradition and Modernity in Arabic Language and Literature, edited by J. R. Smart, 87-101. Surrey 1996.

Speyer, Heinrich. Die biblischen Erzählungen im Qoran. Gräfenhainichen, 1931.

Starcky, Jean. Palmyre. Paris, 1952.

Suvorov, Mikhail N. Al- ${ }^{c}$ Urr i Samar chestvuyut gostey. Prazdnichnaya poeziya iz Yafi ${ }^{c}$ (Yemen) [Russ.: Al- ${ }^{c}$ Urr and Samar celebrate the guests. Festive poetry from Yafi ${ }^{c}$ (Yemen)]. Saint Petersburg, 2003. 
at-Ṭabarī, Abū $\mathrm{Ja}^{\mathrm{c}}$ far Muḥammad b. Jarīr. Tārīkh ar-rusul wa-l-mulūk. Edited by Michael Jan de Goeje. Ser. 1. Vol. 2. Lugduni Batavorum, 1879-1901.

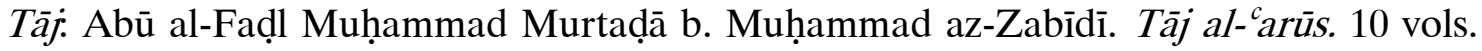
Cairo, 1306ff. (AH).

Talbot Rice, David. "Hira." In Journal of the Royal Central Asian Society 19 (1932): 254-368.

Tha'lab, Abū al-'Abbās Aḥmad b. Yahyyā b. Zayd b. Sayyār ash-Shaybānī. Kitāà alMajālis. Edited by ${ }^{\mathrm{c}}$ Abd as-Salām Muḥammad Hārūn. Vol. 1. Cairo, 1969.

The Book of the Cave of Treasures. Translated by E.A. Wallis Budge. London, 1927.

The History of al-Tabarī (Ta ${ }^{\circ}$ rikh al-rusul wa'l-mulūk), vol. 1. General Introduction and From the Creation to the Flood. Translated and annotated by Franz Rosenthal. New York, 1989.

The History of al-Tabarī (Ta 'rikh al-rusul wa'l-mulūk), vol. 5. The Sāsānids, the Byzantines, the Lakhmids, and Yemen. Translated and annotated by C.E. Bosworth. New York, 1999.

Toepel, Andreas. Die Adam- und Seth-Legenden im syrischen Buch der Schatzhöhle. Eine quellenkritische Untersuchung. Louvain, 2006.

Toral-Niehoff, Isabel. "Eine arabische poetische Gestaltung des Sündenfalls. Das vorislamische Schöpfungsgedicht von "Adī b. Zayd." In "Im Vollen Licht der Geschichte": Die Wissenschaft des Judentums und die Anfänge der kritischen Koranforschung, edited by Dirk Hartwig, Walter Homolka, Michael J. Marx, Angelika Neuwirth, 235-256. Würzburg, 2008.

Vasilenko, Maxim I. Plemennaya poeziya Aravii kak etnograficheskiy istochnik: ot rannego srednevekovya do nashih dney [Russ.: The tribal poetry of Arabia as ethnographical source: from early Middle ages to our time]. Saint Petersburg, 2007. (Abstract of unpublished thesis).

Wagner, Ewald. Grundzüge der klassischen arabischen Dichtung. Vol. 1. Darmstadt, 1987.

WKAS: Wörterbuch der Klassischen Arabischen Sprache. Edited by Manfred Ullmann. Wiesbaden, $1970 \mathrm{ff}$.

Wright, William. A Grammar of the Arabic language. Third edition. 2 vols. Cambridge, 1896-1898.

Yāqūt, ar-Rūmī al-Hamawī Mu jam al-buldān. Edited by Ferdinand Wüstenfeld. 6 vols. Leipzig, 1866-1873.

az-Zamakhsharī, Abū al-Qāsim Maḥmūd b. 'Umar. Asās al-balagha. Vol. 2. Cairo, 1923. 